\title{
A Semidemocracia Brasileira: autoritarismo ou democracia?
}

JOSÉ MARIA PEREIRA DA NÓBREGA JR."

\section{Resumo}

No Brasil a democracia ainda não se consolidou. Temos o que Mainwaring et al. (2001) chamaram de semidemocracia, i.e., um regime político que se caracteriza pelo seu hibridismo institucional, ora apresentando características avançadas da democracia (política), ora apresentando características visivelmente autoritárias. O propósito do artigo é discutir a semidemocracia brasileira utilizando como termômetro de análise as instituições do poder coercitivo estatal. O sistema de justiça e a segurança pública estão aqui analisados numa visão em que a explicação política e a histórica se completam. Numa concepção minimalista da democracia analiso algumas instituições coercitivas verificando a teoria com a realidade formal e informal dessas instituições.

Palavras-chave: Semidemocracia. Devido Processo Legal (Penal). Due Process of Law. Polícia e Relações Civil-Militares.

* Doutorando em Ciência Política pela UFPE e pesquisador do NIC - Núcleo de Estudos em Instituições Coercitivas da UFPE. Agradeço a colaboração importante do parecerista da Revista Sociologias, destacando desde já, que todas as informações e conceitos aqui contidos são de minha inteira responsabilidade. 


\section{Introdução}

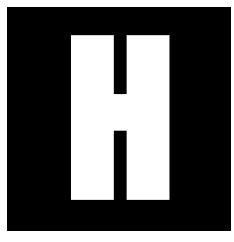

á uma ideia hegemônica de que a democracia no Brasil está consolidada. Discordo desta avaliação. O Brasil é uma semidemocracia. Por definição, é uma situação em que uma democracia "imperfeita" caminha rumo a uma democracia com sólidas e responsivas instituições. Seria preciso, portanto, dar tempo à mesma. Contudo, passados mais de vinte anos do fim do regime militar, a semidemocracia ${ }^{1}$ brasileira não caminha rumo à superação, de um modo regular, de seus traços mais marcantes.

Há uma insistência na questão da consolidação². Nesse ponto encontro um vazio conceitual. Na verdade, uma "mitologia" da consolidação proporcionada por alguns atores políticos importantes e por uma gama bastante relevante de cientistas políticos nacionais e internacionais que enfatiza apenas o componente eleitoral ou político da democracia brasileira.

O discurso majoritário da consolidação está baseado numa vontade magnânima dos que o defendem. A falta de pressupostos teóricos desse discurso pode ser demonstrada através das palavras de seus propagandistas. Diga-se de passagem, atores políticos de grande impacto no meio político nacional.

Por exemplo, Bresser Pereira (1998) afirmou que "em 1985 o país completou sua transição democrática; em 1988 consolidou-a com a aprovação da Constituição." Em outro momento, o mesmo Bresser Pereira (2003) destacou que a criação do Ministério da Defesa (MD) teria consolidado o regime democrático no Brasil. Também, um ano antes, escreveu que Fernando Henrique Cardoso (FHC), quando assumiu a presidência da República, encontrou consolidada a democracia (BRESSER PEREIRA,

1 O termo semidemocracia será discutido em sua base teórica mais adiante, na seção 3.

2 O termo consolidação deve ser usado com cautela, por se tratar de conceito ex post facto. É importante ressaltar que a literatura definia a democracia chilena, até as vésperas do golpe pinochetista como sendo consolidada. Valendo, também, para a Venezuela antes da primeira tentativa de golpe proporcionada por Hugo Chavez, em 1992 (ZAVERUCHA, 2005). 
2002). O mesmo Fernando Henrique Cardoso, às vésperas de deixar o governo, disse que o Brasil era um dos países mais democráticos do mundo (MACEDO, 2002). Sendo assim, questiono: quando foi consolidada a democracia no Brasil, em 1988, com a promulgação da Constituição, em 1999, quando foi criado o MD, ou quando da assunção de FHC ao cargo de Chefe do Executivo Federal?

Um ano antes da afirmação de FHC de que o Brasil era o país mais democrático do mundo (MACEDO, 2002), o ex-presidente fez alguns questionamentos sobre o risco de retrocesso da democracia no Brasil: "Querem o quê? Acham que a democracia resistirá até onde? Até onde querem levar o povo a descrer nas instituições? A luz amarela está se acendendo. Se a eleição ocorrer neste clima, quem vai segurar o país? Quem segura o mercado?" (O Globo, 23 maio 2001, In: ZAVERUCHA, 2005, p. 13). Tais questionamentos não se justificam em uma democracia consolidada.

Outro ator político que endossa o discurso da consolidação é o expresidente José Sarney. Em 2004, ele afirmou que a democracia foi restaurada e uma das provas disso é que "acabamos toda a legislação autoritária [e que não houve] nenhuma prontidão militar" (SARNEY, 2004). Mesmo tendo a Lei de Segurança Nacional - que reporta a Doutrina de Segurança Nacional do período autoritário -, os Códigos Penal e Processual Penal Militar, a Lei de Imprensa, o Estatuto dos Estrangeiros e o Decreto que dispõe sobre a salvaguarda de dados, informações, documentos e materiais sigilosos de interesse da segurança da sociedade e do Estado no âmbito da Administração Pública, dentre outros, que continuam em vigor. E se não houve prontidão militar, isso se deveu ao fato no qual os civis cederam às pressões militares quando esses ameaçaram utilizar a força (ZAVERUCHA, 2000).

Essa visão majoritária na qual a democracia pode ser percebida nas instituições formais de competição e participação se encontra na maioria dos estudos da ciência política brasileira. Detém-se nos estudos das re- 
lações entre Executivo-Legislativo, observando nas ações de seus atores políticos, o que levam os mesmos a agirem de forma a otimizar ou maximizar racionalmente suas escolhas, descartando a informalidade dessas relações e a especificidade do jogo político no cenário nacional. Fortemente influenciados pela concepção subminimalista de Schumpeter ${ }^{3}$, os estudos sobre o sistema político partidário e do Legislativo-Executivo passam a fazer parte do mainstream da ciência política brasileira, ou seja, o que se estuda para analisar a Finlândia serviria para analisar o Brasil.

Os instrumentos de competição e participação política são de fundamental importância, mas não são suficientes para afirmar que determinado país é uma democracia consolidada, sem riscos de retrocesso, sobretudo na América Latina onde há fraco ethos ${ }^{4}$ democrático. Eleições devem ser seguidas de observações a respeito das instituições coercitivas tais como as polícias, as Forças Armadas, o Ministério Público, o sistema de justiça criminal etc. Numa concepção submínima, que reporta a Schumpeter (1984), tais instituições ficam em segundo plano, apesar delas serem fundamentais para as garantias da soberania nacional e da integridade física dos cidadãos. ${ }^{5}$

Apesar da perspectiva majoritária de atores políticos e de acadêmicos, apenas $37 \%$ dos brasileiros consideram a democracia o "melhor sistema de governo", dados fornecidos pelo instituto de pesquisa chileno Latinobarómetro $^{6}$ confirmam tal afirmativa (ver quadro). Dos 17 países pesquisados por

3 A concepção de Schumpeter sobre a democracia será discutida na seção 2.

4 As virtudes morais vêm do hábito, de onde o seu nome (ethike) é formado a partir de uma leve variação da palavra ethos (hábito) (Ética a Nicômano, livro 2,1ln: FEREJOHN; PASQUINO, 2001, p. 15).

5 No caso brasileiro uma constatação óbvia é que o crime não é punido. No Rio, a taxa de elucidação de homicídios é baixíssima: menos de $3 \%$. Praticamente ninguém é condenado se não for pego em flagrante. Nos EUA, em 65\% dos homicídios pelo menos um dos acusados é levado a julgamento. Se a polícia fluminense tivesse metade da eficácia da americana, a taxa de homicídio provavelmente cairia quase $40 \%$. (SHEINKMAN, 2007, p. 90).

6 Disponível em: http://www.latinobarometro.org/ano2003/Inform-Resumen_Latinobarometro_2003.pdf 
essa instituição, o Brasil é o que apresenta o índice mais baixo de crença na democracia como o melhor sistema de governo. Disso tudo, questiono: em que direção a democracia brasileira está caminhando. Para a consolidação, está retrocedendo ou está engessada? Por que o povo brasileiro desconfia da democracia? Qual o conceito de democracia está nos baseando?

Tabela 1. Percentual da população que prefere a democracia

\begin{tabular}{|c|c|c|c|c|}
\hline & 1996 & 2000 & 2001 & 2002 \\
\hline Honduras & 42 & 64 & 57 & 57 \\
\hline Venezuela & 62 & 61 & 57 & 75 \\
\hline México & 53 & 45 & 46 & 63 \\
\hline Nicarágua & 59 & 64 & 43 & 63 \\
\hline Uruguai & 80 & 84 & 79 & 78 \\
\hline Equador & 52 & 54 & 40 & 49 \\
\hline Costa Rica & 80 & 83 & 71 & 77 \\
\hline Chile & 54 & 57 & 45 & 50 \\
\hline Argentina & 71 & 71 & 58 & 65 \\
\hline Peru & 63 & 64 & 62 & 57 \\
\hline Guatemala & 51 & 45 & 33 & 45 \\
\hline Bolívia & 64 & 62 & 54 & 56 \\
\hline Brasil & 50 & 39 & 30 & 37 \\
\hline Paraguai & 59 & 48 & 35 & 45 \\
\hline El Salvador & 56 & 63 & 25 & 40 \\
\hline Panamá & 75 & 62 & 34 & 55 \\
\hline Colômbia & 60 & 50 & 36 & 39 \\
\hline
\end{tabular}

Fonte: Latinobarómetro

Os dados positivos em relação a Evolução da pobreza e indigência no Brasil (1999 a 2005), onde a indigência caiu em 4,6 milhões de pessoas e a pobreza em 4,9 milhões (PRADO, 2006, p. 123), não diminui a desconfiança a respeito da democracia que permanece e parece não estar 
ligada a questões de desenvolvimento econômico, mas sim de eficiência das instituições que utilizam a força (WEBER, 1999).

Isso me levou a refletir a respeito do vazio conceitual que há sobre a definição de democracia ${ }^{7}$ consolidada. Conciliar o aspecto formalprocedural (NÓBREGA JÚNIOR, 2004) da democracia com conteúdo democrático se mostra como um grande desafio. O ex-presidente das Filipinas, Fidel Valdez Ramos, escreve, em poucas palavras, o que significa tal desafio: "o desafio político para os povos de todo o mundo atualmente não é substituir regimes autoritários por democráticos. É, além disso, fazer a democracia funcionar para as pessoas comuns." ${ }^{8}$

O presente trabalho tem como proposta discutir as bases teóricas da semidemocracia, conectando essa perspectiva para o caso brasileiro. Busco aqui retratar como algumas instituições do poder coercitivo do estado brasileiro infringem em aspectos normativos do conteúdo liberal, ferindo direitos fundamentais. Para isso, o artigo vem divido em partes, onde, inicialmente, a análise contemplará um confronto entre os modelos procedurais e não-procedurais da teoria democrática (NÓBREGA JÚNIOR, 2004), partindo, em seguida, para uma discussão a respeito do efeito benéfico e, ao mesmo tempo, defeituoso de Schumpeter em sua contundente análise da democracia, contemplando o fim da teoria clássica, "desmascarando-a", sendo base de estudos contemporâneos da teoria política (PRZEWORSKI, 1999; PRZEWORSKI et al, 2001). Em seguida, discuto o conceito de semidemocracia baseado no trabalho de Mainwaring et al (2001) onde estes autores trabalham o conceito de subminimalismo encontrado na definição de democracia schumpeteriana que será a base teórica dos estudos de Przeworski et al (2000) e de outras análises

7 Salientar que o modelo colocado como "tipo ideal" está configurado no modelo estadunidense de democracia, sobretudo no que diz respeito à igualdade jurídica.

8 Citação retirada de Sen (1999, p. 183). 
sobre regimes políticos democráticos contemporâneos. Aí destaco a base teórica a qual me baseio para levantar o debate sobre democracia, sobretudo nos países latino-americanos - onde o Brasil se encontra de forma destacada-, introduzindo instituições que não são contempladas numa perspectiva (sub)mínima, esta baseada em análises onde a competição e a participação política nos processos eleitorais e partidários é que contam, que são as instituições coercitivas responsáveis pela implementação do Estado de Direito democrático e, por sua vez, por garantias de liberdades fundamentais. Na seção seguinte, faço um confronto entre os modelos de Sistema de Justiça no que tange ao Devido Processo Legal (Due Process of Law) do Brasil e dos Estados Unidos, onde a diferença de um modelo inquisitorial do primeiro se choca com o modelo acusatorial angloamericano que prima pela garantia de direitos fundamentais individuais. Posteriormente, me dedico a análise da Segurança Pública, mostrando como o processo de militarização da mesma recrudesceu com a redemocratização fazendo com que traços autoritários fossem mantidos ou, até mesmo, robustecidos. A conclusão contemplará a análise como um todo, mostrando como a semidemocracia brasileira se constitui numa realidade, e que a sua superação depende da consolidação de certos critérios imprescindíveis para um eficiente ordenamento social e político, onde a democracia deve ser vista como o meio de administrar as relações de poder com o intuito de minimizar a dominação (SHAPIRO, 2003).

\section{Democracia procedural x democracia não-procedural}

Sem direitos do homem reconhecidos e protegidos, não há democracia; sem democracia, não existem as condições mínimas para a solução pacífica dos conflitos. (BOBBIO, 1992) 
Na teoria democrática existem dois grandes campos de análise. Um conhecido como processual ou procedimental, que reporta a Schumpeter (1984) e sua concepção elitista da teoria democrática, e outro conhecido como não-procedural, onde questões normativas de base qualitativa são atributos no estudo da análise democrática (HABERMAS, 1997; TAYLOR, 2000; VITA, 2002). Há uma distância considerável entre as duas formas de se definir um regime democrático nessas duas concepções. Parte dessa distância entre as duas faces da democracia é o fato dos regimes democráticos contemporâneos serem entendidos e vividos a partir de pressupostos - sobre a natureza humana e sobre a organização das sociedades - emprestados de uma corrente teórica que nasceu para afirmar a impossibilidade das democracias: a chamada "teoria das elites". ${ }^{9}$ Aqui, me concentro no campo procedural. Nele existem dois subcampos, um minimalista e outro subminimalista.

As divergências entre esses dois subcampos de análise procedural de democracia encontram-se em suas formas de classificação dos regimes políticos. Isso tem como ponto de partida as diferenças em suas formas de definição da democracia. Ambas se concentram em determinados procedimentos ou regras do jogo. Equiparam a democracia à realização de eleições livres e limpas, onde exista alternância de poder, sem que haja restrições às liberdades civis e políticas ou espaços reservados a atores políticos não eleitos que agem politicamente restringindo poder dos eleitos (MAINWARING et al, 2001). Mas, definições submínimas diferem da

9 "Fundadores dessa corrente, Mosca, Pareto e Michels, não escondiam sua oposição aos movimentos democráticos e socialistas presentes na virada do século XIX para o XX. Suas obras revelam a apreensão com a atuação desses movimentos e buscam demonstrar que seus objetivos igualitários eram ilusórios. Segundo eles, sempre vai haver desigualdade na sociedade, em especial a desigualdade política. Isto é, sempre existirá uma minoria dirigente e uma maioria condenada a ser dirigida, o que significa dizer que a democracia, enquanto 'governo do povo', é uma fantasia inatingível. Pois é exatamente esta visão que, sobretudo a partir da obra de Schumpeter, publicada nos anos 1940, se torna a base da tendência dominante na teoria democrática - e penetra profundamente na concepção corrente sobre a democracia" (MIGUEL, 2002, p. 485). 
minimalista por questão de seus critérios de codificação. Tais critérios estão sujeitos a uma visão dicotômica dos regimes políticos: democracia ou nãodemocracia (autoritarismo). A concepção submínima se interessa exclusivamente no aspecto eleitoral não dando relevância a outras instituições que não passam pelo crivo eleitoral, mas são imprescindíveis para o bom andamento do regime democrático. Questões como o respeito aos direitos civis e a força política de outros atores não eleitos, como as Forças Armadas, por exemplo, são negligenciadas pelo subminimalismo democrático. No caso da definição minimalista, a maioria dos países classificados em uma análise subminimalista cai numa zona cinzenta - pois a maioria deles respeita as eleições como mecanismo de escolha, mas despreza certos direitos civis, como a questão da justiça equânime e a efetiva condução das Forças Armadas sob o jugo civil - entre os dois regimes políticos, sejam eles a democracia e o autoritarismo. Esta zona cinzenta seria a condição para chamarmos o país que se enquadrasse nela de semidemocrático ou semi-autoritário. Isso denotaria uma tricotomia ou quadricotomia. Em definições submínimas, como as de Schumpeter (1984) e Przeworski et al (2000), o Brasil contemporâneo é classificado como sendo uma democracia. Tal afirmação se mostra frágil quando partimos para a análise de outros critérios que não apenas aqueles relacionados à competição e a participação eleitoral.

Sendo assim, vou partir da análise teórica explorando-a, de forma mais esmerada, buscando perceber como surgiu essa concepção subminimalista da democracia e como ela desenvolveu-se no decorrer do tempo em outras teorizações e definições. 


\section{O (sub)minimalismo e a teoria democrática}

\section{Schumpeter e o fim da Teoria Clássica}

Weber (1999), em sua análise do Estado Moderno e da sociedade capitalista, no livro Economia e Sociedade, inicia seu discurso com uma afirmação bastante pertinente: O Estado, no sentido do Estado Racional, somente se deu no ocidente (WEBER, 1999, p. 517). A racionalidade tem papel fundamental em toda a construção teórica da sociologia weberiana. A sociedade industrial do século XX, em sua grande complexidade, exigiu uma profunda transformação nas bases do Estado. Neste, o que veio prevalecer foi a sistematização e a racionalidade como pontos chave de sua formação. Weber produziu uma das mais relevantes definições do Estado Moderno (HELD, 1987).

O Estado Racional da modernidade antecedeu e ajudou a promover o desenvolvimento do capitalismo. O capitalismo, por sua vez, corroborou a necessidade de maior sistematização do Estado moderno. Tal sistematização trouxe para a sociedade reflexos que a transformaram. A racionalidade, segundo Weber, foi a responsável pela "desmistificação" da sociedade. Antes da ascensão da razão e do conhecimento, o que existia era a supremacia da religião e de virtudes morais e éticas pré-estabelecidas. Com a era da razão têm-se edificado uma "nova realidade" quase que completamente desprovida daqueles aspectos. A racionalidade trouxe consigo a técnica e a ciência e isso perpassou para a política, a economia e a sociedade.

Para Weber, o aparelho burocrático do estado seria o instrumento pelo qual a garantia da ordem liberal e da democracia seria efetivada, evitando assim que determinados grupos ou facções se perpetuassem no poder político. As regras do jogo democrático seriam garantidas por tal burocracia. Mas, ao mesmo tempo deveria existir uma instituição que limitasse a ação 
da burocracia estatal. O parlamento aparece como a instituição que serviria de limite à burocracia. Para tanto, no parlamento ter-se-ia o elemento político, já que a burocracia não poderia assumir esta atividade.

O parlamento seria o órgão que ficaria responsável pelas decisões políticas da sociedade e do Estado. Mas os indivíduos que o formariam deveriam passar por algum processo, já que não poderiam utilizar os mesmos critérios de seleção utilizados pela burocracia (que exige a comprovação de certas habilidades técnicas). Esse processo vai ser encontrado na definição do método democrático que tem início com Weber.

A democracia, na concepção de Weber, tinha caráter processual. Para ele só se conceberia a democracia como sendo um mecanismo de escolha individual dos líderes e de competição eleitoral pelo voto do cidadão. A democracia direta seria impraticável na sociedade moderna e industrial do século XX. ${ }^{10}$ Enxergava na democracia direta uma série de dificuldades em sua aplicabilidade em uma realidade tão heterogênea e complexa como aquela vivida pela sociedade moderna. Weber definiu democracia como sendo um mecanismo institucional de seleção de políticos competentes e capacitados. Para ele a democracia seria uma "seleção natural" de líderes competentes para a formação do parlamento. O povo ficaria restrito à escolha dos seus representantes, tais representantes escolhidos de um grupo elitista de políticos profissionais.

Weber tinha uma concepção restrita da vida política, onde não havia espaço abrangente para a participação política. Schumpeter seguiu a mesma linha de Weber, para ambos a coletividade era uma constante ameaça a estrutura do Estado.

10 Apesar de afirmar que a democracia direta poderia existir sob certas condições. 1) a organização deve ser local ou limitada de alguma forma em termos do número de seus membros; 2) as posições sociais dos membros não devem diferir grandemente umas das outras; 3 ) as funções administrativas devem ser relativamente simples e estáveis; 4) Deve haver um desenvolvimento mínimo de treinamento de formas e meios objetivamente determinados. (Economia e Sociedade, vol. II, p. 949). 
Weber estruturou toda uma visão burocratizada da democracia que foi absorvida e fortalecida por Schumpeter na década de 40 do século passado (HELD, 1987). A visão da incompetência dos cidadãos médios para assuntos públicos e a necessidade de criação de partidos políticos no lugar da democracia direta, são pontos que perpassaram para a análise de Schumpeter. Aqueles partidos teriam de disputar os votos num amplo "mercado" político competitivo e teriam também de racionalizar suas estratégias para lograrem êxito em seus intentos.

Schumpeter (1984) criticou a teoria clássica da democracia de forma a levantar, segundo ele, falhas conceituais que não mais se adequavam à realidade do século XX. A Teoria Clássica de democracia surgiu no século XVIII, em um momento histórico onde as estruturas da sociedade inspiravam mudanças por parte do estado. Este estado nascente refletia as ideias e perspectivas da classe em ascensão naquele momento, a burguesia. O liberalismo, que se tornou a filosofia política da classe burguesa, alicerçou os pensamentos de filósofos que introduziram a filosofia utilitarista no âmbito da sociedade burguesa. Os interesses dos indivíduos estariam acima de quaisquer outros interesses e daí surgiria o bem comum como sendo o resultado de um "propósito comum" dos interesses individuais. Mesmo os não-utilitaristas como Rousseau, compartilhavam da conceituação de um bem comum universal. As definições de bem comum, vontade do povo, vontade geral, segundo a teoria clássica, não tinha sentido para Schumpeter.

A teoria clássica seria na verdade uma ficção, pois os cidadãos são totalmente desprovidos de razão quando o assunto envolve questões políticas. As definições de bem comum, vontade da maioria e vontade do povo são conceitos que variam de acordo com os interesses daqueles que se envolvem na política, ou seja, são manufaturados por eles. O bem comum aparece como algo que não pode ser definido de forma coerente, pois a sua concepção para diferentes grupos dentro de uma sociedade pode se mostrar de forma multifacetada: 
Não existe algo que seja um bem comum unicamente determinado, sobre o qual todas as pessoas concordem ou sejam levadas a concordar através de argumentos racionais (...) para diferentes indivíduos e grupos, bem comum está fadado a significar diferentes coisas (SCHUMPETER, 1984, p. 314-315).

A doutrina clássica traz a vontade geral como sendo o substrato das vontades dos indivíduos (ROUSSEAU, 1997). As vontades dos indivíduos podem ser as mais diversas possíveis e para se chegar a uma conclusão do que é a vontade do povo tem-se que levar em consideração as mais variadas formas de vontades dos indivíduos em sociedade. A vontade do povo e a vontade da maioria podem divergir em vários aspectos, a universalização desses termos mostra-se equivocadamente errada (SCHUMPETER, 1984, p. 318-319).

Schumpeter (1984) fez a revisão da doutrina clássica para chegar a conclusão de que a mesma não condiz à realidade da sociedade industrial do século XX. A doutrina clássica é um credo no qual os homens encontraram o substituto da religião, da moral e da ética medieval. Para Schumpeter (1984), a doutrina clássica da democracia aparece como um ideal incorporado por grupos que só pretendem proteger os seus interesses:

A revolução democrática significou o advento da liberdade e da decência, e o credo democrático significou um evangelho de razão e de melhorias. É certo que essa vantagem estava fadada a se perder e o abismo entre doutrina e prática da democracia estava destinado a ser descoberto. Mas o encanto da aurora demorou a desfazer-se. (...) Os políticos apreciam uma fraseologia que lisonjeie as massas e que ofereça excelente oportunidade não apenas de fugir à responsabilidade, mas também de esmagar os oponentes em nome do povo (SCHUMPETER, 1984, p. 334).

Utilizando a doutrina clássica e seu ideal humanístico, muitos políticos que na verdade não estariam interessados em pressupostos humanísticos, poderiam usar tal doutrina no intuito de "ludibriar" as massas. O dis- 
curso intrínseco naquela doutrina, para Schumpeter não passava de um "rito utópico" impraticável que serviria como subterfúgio para políticos mal intencionados. E, sendo assim, estaria aí a posição na qual Schumpeter acreditaria estar perpetuada a doutrina clássica da democracia.

As mudanças advindas com o avanço tecnológico e com as revoluções no mundo do trabalho trouxeram uma nova perspectiva para o conceito de democracia. A democracia passaria a ser vista como um método de escolha de representantes em um contexto de competição política pelo voto dos cidadãos. A democracia passou a ser vista como um mecanismo, não mais como um ideal:

Por democracia, Schumpeter queria se referir a um método político, ou seja, uma estrutura institucional para chegar a decisões políticas (legislativas e administrativas) investindo certos indivíduos com o poder de decidir sobre todas as questões como consequências de sua dedicação bem sucedida à obtenção do voto popular (HELD, 1987, p. 151).

Para Schumpeter, a democracia da teoria clássica não passava de um ideal irrealista. Na verdade, a democracia seria um método de escolha de governantes e o povo seria um ator passivo. A partir dessas reflexões abremse os seguintes questionamentos: qual a consistência da democracia para Schumpeter? O que caracterizam os seus "ingredientes" principais?

No que diz respeito à democracia real de Schumpeter, esta é "um mecanismo que permite o registro de desejos mais amplos das pessoas comuns, o que deixa a verdadeira política pública nas mãos dos poucos suficientemente experientes e qualificados para fazê-la" (HELD, 1987, p. 151). A democracia como método real e aplicável deveria excetuar a tirania da maioria e restringir a participação política dos cidadãos apenas ao aspecto de escolha de seus líderes. Estes viriam de escalóes da elite política, os políticos profissionais, que, como o empresário no mercado tenta maximizar suas ações para obter maiores lucros, deveriam utilizar 
todos os recursos para a obtenção da maioria dos votos dos cidadãos numa competição livre por tais votos. Os políticos estariam inseridos em partidos que teriam como principal objetivo chegar ao poder ou manterse nele (SCHUMPETER, 1984). Obtendo êxito na disputa, o político vitorioso assumiria o poder onde permaneceria até as próximas eleições.

A participação política se restringe à escolha dos representantes. $\mathrm{O}$ debate político fica restrito à elite política eleita. Segundo a concepção schumpeteriana:

a democracia não significa e não pode significar que o povo realmente governa em qualquer sentido óbvio dos termos "povo" e "governo". A democracia significa apenas que o povo tem a oportunidade de aceitar ou recusar os homens que os governam (HELD, 1987, p. 152).

Schumpeter percebia o cidadão como um "fantoche" nas mãos da opinião pública pré-fabricada pela propaganda. A opinião popular era manufaturada facilmente pelos veículos midiáticos e por aqueles que estivessem dispostos a persuadir as massas no intuito de fazer prevalecer os seus interesses mais imediatos. As decisões políticas teriam de ficar no âmbito do parlamento tal como Weber diagnosticou. A política, no entanto, não seria atividade para pessoas que não os políticos profissionais advindos de elites políticas com alta capacidade técnica e de aparelhos burocratizados que seriam os partidos políticos.

Portanto, a teoria democrática de Schumpeter é conhecida como tendo caráter minimalista - na perspectiva aqui explorada, submínima (MAINWARING et al, 2001) - pois na sua argumentação a democracia:

pode suportar, na melhor das hipóteses, apenas um envolvimento político mínimo: aquele tipo de envolvimento que poderia ser considerado suficiente para legitimizar o direito das elites políticas em condições de competir para governar (HELD, 1987, p. 153). 
No que diz respeito à competição pelos votos, Schumpeter acompanha Weber no quesito da formação dos partidos políticos. Estes existem por questão da incapacidade dos cidadãos em seguir um ordenamento em suas ações políticas. Os partidos políticos seguiriam as regras eleitorais e articulariam suas estratégias no sentido de alcançarem os melhores resultados nas eleições. Eles representariam, de forma organizada e burocratizada, os anseios dos grupos de cidadãos.

Schumpeter afirmou que para o método democrático ter eficiência é necessário o preenchimento de certas condições:

1. O calibre dos políticos deve ser alto, ou seja, a qualificação profissional das lideranças políticas;

2. A competição entre líderes (e partidos) rivais deve ter lugar dentro de uma esfera relativamente restrita de questões políticas, vinculadas por consenso à direção geral da política nacional, ao que constitui um programa parlamentar razoável e a questões constitucionais gerais;

3. Um corpo burocrático bem treinado e independente, de "boa posição e tradição", deve existir para ajudar os políticos em todos os aspectos da formulação e administração da política;

4. Deve haver um "autocontrole democrático", ou seja, uma ampla concordância sobre o fato de que, por exemplo, coisas como a confusão entre os respectivos papéis dos eleitores e dos políticos, um excesso de críticas ao governo em todas as questões e comportamentos são indesejáveis. Cabe ao governo impor a si limites quando certas questões ultrapassarem sua esfera de conhecimento, algumas questões têm de ser entregues a especialistas;

5. Deve haver uma cultura capaz de tolerar diferenças de opinião (HELD, 1987, p. 160). 
As concepções de Schumpeter estimularam muitos argumentos para os seus críticos. Reduzir a democracia a um método de escolhas e ao indivíduo uma total incapacidade de discutir problemas políticos, fez com que vários estudiosos argumentassem contra a posição de Schumpeter. "Se a democracia clássica (...) não existe, apenas este fato não prova que ela é impossível" (HELD, 1987, p. 163). A democracia clássica do século XVIII nasceu como um movimento de crítica à dominação política da aristocracia. Para os democratas clássicos, o cidadão aparece como agente potencial e a vontade geral como o que existe de comum a todas as vontades individuais, ou seja, o substrato coletivo das consciências (ROUSSEAU, 1997, p. 185). Mas, segundo Schumpeter, o cidadão comum é irracional para assuntos políticos.

De acordo com a crítica de Held (1987), a teoria de Schumpeter estaria mais próxima de uma visão antiliberal e antidemocrática. O’Donnell (1999) também ressalta o caráter (sub)minimalista da teoria de Schumpeter destacando a questão das liberdades exigidas para que exista sucesso do método democrático. Para O’Donnell (1999) o caráter (sub)minimalista de Schumpeter não procede, pois para que existam as condições que Schumpeter enumera para a eficácia do método democrático é de fundamental importância o respeito de certas atribuições do Estado de direito, bem como a formação de uma cultura "tripartite" da sociedade civil, ou seja, onde as prerrogativas liberais, republicanas e democráticas façam parte da cultura política do cidadão. Mas, existem defensores do (sub)minimalismo schumpeteriano, como Przeworski (1999) e Przeworski et al (2000), que enveredaram por uma análise processual de democracia com grande eficácia teórica.

Dentro desse contexto, seguindo a linha schumpeteriana, tem-se desenvolvido a concepção que segue a visão "mercadológica" da política11. Os políticos são vistos como atores que buscam, a todo custo, maximizarem

11 Importante ressaltar que J. Schumpeter era economista, daí a grande influência sofrida por sua teoria do aspecto economicista. 
suas ações em prol da otimização dos seus interesses. Essa abordagem de caráter economicista traz para a discussão da política um viés mais realista e quantitativo da teoria democrática, onde a participação e a competição no processo eleitoral são pontos centrais para a realização da democracia.

Dessa forma, os estudos de grupo e de ação coletiva passaram a visualizar o indivíduo como principal agente e não a coletividade. Olson (2002) afirma que dentro de um grupo que tem um interesse comum também encontramos interesses estritamente individuais. Tais interesses podem diferir dos interesses da organização ou do grupo. O indivíduo, independentemente de seu ideal de grupo, tem seus interesses particulares. Nessa perspectiva o indivíduo que está inserido em um grupo latente, ou grande grupo, tem poucos estímulos para a participação política em prol de bens públicos coletivos. Olson (2002) compara o indivíduo à empresa no mercado competitivo, sua participação ou não-participação dependerá das oscilações mercadológicas. O esforço dispensado em prol de um benefício público em um grande grupo será desfrutado com a participação do indivíduo ou com sua ausência no processo. Dessa forma, a tendência a não querer participar do ônus da participação prevalecerá. ${ }^{12}$ O bem público será desfrutado mesmo sem a participação. Para existir uma maior eficácia da democracia vai ser fundamental a formação de pequenos grupos ou comitês (OLSON, 2002, p. 66). Para Olson (2002), os pequenos grupos têm maior eficiência quando a perspectiva é a ação, os grupos latentes ou grandes grupos teriam melhor desempenho como arenas de discussão, numa visão da democracia como fórum.

Contudo, a visão (sub)minimalista da democracia coloca o elemento procedural como ponto chave da teoria. Como num mercado o indivíduo escolherá, de acordo com suas preferências, a plataforma que mais condiz com suas necessidades. O partido ou indivíduo eleito vai buscar otimizar suas ações tendo como principal intuito manter-se no poder e/ou ser

12 Nesse ponto Reis (2002) levanta uma crítica ao trabalho de Olson. Para ele, não necessariamente aqueles que se abstém da participação do processo político são beneficiários. 
reeleito numa próxima eleição. Caso consiga seu intento provar-se-á que sua conduta no governo foi aprovada pela maioria范; sendo negativa a sua empreitada, teremos sua reprovação consolidada nas urnas (PRZEWORSKI, 1999, p. 23-55). Przeworski defende a concepção (sub)minimalista, pois é o único mecanismo em que conflitos são resolvidos sem derramamento de sangue. A democracia, nessa perspectiva, nos permite livrar-se de governos de forma pacífica. Seria o melhor meio para a regulação dos conflitos, pois dificilmente deixará de existir conflitos. Baseado numa concepção submínima, Przeworski (1999) releva questões que são importantes:

Ainda assim este milagre (democracia) não opera sob todas as circunstâncias (...) Lipset $(1959,46)$ estava indubitavelmente correto quando ele disse que 'quanto mais próspero um país, maior é a chance que ele sustentará democracia.

Przeworski (1999) também destaca o aspecto institucional, "uma concepção minimalista da democracia não suaviza a necessidade de pensar em design institucional" (PRZEWORSKI, 1999, p. 49-50). Contudo, para este autor há uma "cultura do lamento" na América Latina, onde a democracia avançou e que os problemas de desigualdade social e política, e eu acrescento civis, não são reflexo da debilidade dos mecanismos de accountability eleitoral, horizontal ou social. A democracia estaria muito bem em nossas plagas, pois os problemas da democracia enfrentados na América Latina são mais agudos no continente europeu:

Soy escéptico respecto de que el alto grado de desigualdad y la persistência de la pobreza em América Latina se debían a la

13 Uma perspectiva submínima é perigosa, pois se um corrupto que renuncia é eleito numa próxima eleição esta definição endossa um mau comportamento. Para o caso brasileiro isto fragiliza a democracia, políticos renunciam, dessa forma, não perdem seus direitos políticos. Candidatam-se numa próxima eleição e conseguem vencer, mesmo com uma conduta amoral no mandato anterior ele pode afirmar que o povo o "absolveu". José Arruda, governador eleito pelo Distrito Federal nas últimas eleições majoritárias fez este discurso. Este ator político foi acusado no escândalo do painel do senado, renunciou em meio ao processo e garantiu seus direitos políticos. Se candidatou e ganhou a eleição e disse que o povo o tinha absolvido. 
debilidad de los mecanismos de accountability electoral, horizontal o social. Sin embargo, aún es necesario produndizar las investigaciones en el área para descubrir la verdadera causa - o las causas - que provoca esta situación (PRZEWORSKI, 2001).

A perspectiva submínima concebida por Przeworski em seus trabaIhos o leva a não enxergar pontos fundamentais para a democracia. $\mathrm{Na}$ próxima seção será fortalecida a teoria da semidemocracia onde o minimalismo e o subminimalismo são confrontados.

\section{A semidemocracia: uma zona cinzenta como área das democracias "imperfeitas"}

\section{Minimalismo e subminimalismo}

O subminimalismo é característico das definições sobre a democracia que tem como critérios aqueles elencados por Schumpeter (1984), onde a democracia é vista como um método de escolha dos governantes, i.e., as eleições são o foco (HELD, 1987, p. 160). Parto do pressuposto de que para existir de forma mínima uma democracia tais critérios são fundamentais: 1) promover eleições diretas, competitivas, livres e limpas para o Legislativo e o Executivo; 2) pressupor uma cidadania adulta abrangente e inclusa no processo de escolha (voto $)^{14} ; 3$ ) proteger as liberdades civis e os direitos políticos ${ }^{15}$ e 4 ) efetivar governos eleitos que de fato governem e

14 Em uma democracia a participação política de um cidadão é expansiva para a maioria da população adulta. Encontrar-se-á violação desse critério se uma grande parcela da população adulta for privada desse direito, por quaisquer motivos, sobretudo os étnicos, de classe, de gênero ou de nível de instrução. Tais restrições podem levar a um resultado eleitoral distorcido e excludente.

15 Violações aos direitos humanos não são comuns em uma democracia. Nela, também, os partidos são livres para se organizar e o governo respeita as garantias contidas na constituição (MAINWARING et al, 2001). O componente liberal encontrado na constituição tem de estar em sintonia com o Judiciário. Regras e códigos de jurisprudência que não vinculam a igualdade perante a lei aos seus códigos e condutas, não podem estar compromissados com o Estado de Direito democrático. 
onde os militares estejam sob jugo dos civis $^{16}$ (MAINWARING et al, 2001, p. 645). Esses critérios incorporam a definição minimalista, onde esta contrasta com as não-procedurais e, também, com as submínimas baseadas em critérios meramente eleitorais. ${ }^{17}$

Os dois primeiros critérios da análise minimalista aqui colocados são apreciados pelas definições submínimas de Schumpeter (1984) e Przeworski et al (2000), mas os outros dois critérios não são contemplados na tipologia classificatória desses autores. Para a perspectiva minimalista da democracia, há no subminimalismo um sério equívoco. Garantir efetivas e sólidas instituições que garantam as liberdades civis e o efetivo controle civil das instituições de segurança - Poder Judiciário, Polícias, e Forças Armadas - é fundamental para a democracia, mas não é para os subminimalistas.

Os critérios mínimos aqui defendidos são necessários para a democracia. A definição procedural minimalista focaliza as regras do jogo eleitoral, mas acrescenta uma preocupação com as liberdades civis e com a genuína capacidade de exercer o poder. Tal definição não aborda a questão nãoprocedural, detêm-se nos aspectos do Estado de Direito na garantia das liberdades individuais e na efetividade do controle civil sobre os militares.

\section{A semidemocracia}

Como atribuir o caráter de democracia "consolidada" quando da análise de outros parâmetros que não estejam inseridos nas instituições que

16 Em uma democracia, os líderes militares ou os militares como instituição têm influência insignificante ou negligenciável em áreas de política que não se relacionam especificamente com as Forças Armadas e suas preferências não afetam substancialmente as chances dos candidatos presidenciais (MAINWARING et al, 2001, p. 660).

17 Avaliar regimes políticos apenas em seu aspecto eleitoral exclui elementos essenciais para uma democracia em bases sólidas. Estudos que se baseiam apenas em eleições são submínimos e omitem pontos que são fundamentais para uma análise sobre regimes políticos democráticos. Eleições aparecem como um componente importante, mas não suficiente para a afirmação de que em determinado país exista democracia consolidada. 
passam pelo crivo eleitoral? Por exemplo, se direitos fundamentais, como o que diz respeito a um julgamento justo e isonômico, são impedidos de ser garantidos por enclaves hierárquicos e autoritários dentro do sistema de justiça? Como é o caso do paradoxo entre a Constituição de 1988 e os códigos penais brasileiros em muitos de seus artigos. As premissas básicas do Estado Moderno, como o que diz respeito aos direitos civis, não são respeitadas e efetivamente garantidas para a maioria dos cidadãos brasileiros. As Instituições de Segurança Pública apresentam sérios problemas que ameaçam o próprio Estado de Direito democrático ${ }^{18}$, problemas estes no âmbito formal e informal. Ameaças que levam à crise do Estado Legal no Brasil. ${ }^{19}$ Todas as questões aqui apontadas devem ser levadas em consideração para se afirmar que o Brasil é uma democracia consolidada, não podendo ser negligenciada numa perspectiva procedural minimalista da democracia.

O conceito minimalista de democracia, ou democracia procedural, ou ainda, democracia como método de escolha de governantes, tem sua origem nos estudos de Schumpeter (1984) e Weber (1999) (NÓBREGA JúNIOR, 2004 e 2005). Contudo, tal conceito é submínimo (MAINWARING et al, 2001), não minimalista. A democracia de caráter "schumpeteriano" seria submínima por não alcançar parâmetros que são fundamentais para a afirmação de que o regime político de um país seja democrático. Em estudo comparativo de regimes políticos na América Latina, que abrange

Depois de 15 anos de democracia eleitoral, a Tailândia sofreu um golpe militar em setembro de 2006. O seu primeiro ministro, Thaksin Shinawatra, acusado de corrupção e má administração do poder público, foi afastado do governo. Se ele se mostrou indigno para o cargo, seria pelas eleições ou outro processo legal que deveria ter sido afastado e não por um golpe castrense. Eleições são importantes, mas não são suficientes para a consolidação da democracia.

18 Art. 144 da Constituição Brasileira de 1988. A segurança pública, dever do Estado, direito e responsabilidade de todos, é exercida para a preservação da ordem pública e da incolumidade das pessoas e do patrimônio(...) Percebendo sérios problemas nessas instituições, venho aqui sugerir uma maior atenção a tais instituições que não são contempladas pelos trabalhos baseados em pressupostos submínimos, mas são de fundamental importância para a consolidação de um regime democrático.

19 “'Estado Legal', isto é, a parte do Estado que é personificada num sistema legal, penetra e estrutura da sociedade, fornecendo um elemento básico de previsibilidade e estabilidade às relações sociais" (O’DONNEL, 2000, p. 347). 
um corte temporal que vai de 1945 a 1999, Mainwaring et al (2001) destacaram os trabalhos de Schumpeter (1984), Przeworski et al (2000) e de instituições que fazem análises de gradação democrática para a América Latina, como a Polity III e a Freedom House, colocando-os como sendo submínimos por não abordarem parâmetros bastante pertinentes para a análise de regimes políticos democráticos. Criaram uma escala tricotômica na qual o país em análise seria classificado como democrático, autoritário ou semidemocrático (ou semiautoritário), diferenciando-se das teorias submínimas, que levam em consideração apenas as instituições que passam pelo crivo eleitoral. Para os subminimalistas, regimes onde não existem eleições com aquelas características ("schumpeterianas"), seriam autoritários. Configurando, dessa forma, uma interpretação dicotômica da análise democrática, ou seja, submínima. Numa escala quadricotômica, tem-se uma zona cinzenta na qual o país em análise que se encaixe nesta zona aparece como tendo um sistema político híbrido, nem autoritário, nem democrático, possuindo, na verdade, elementos de ambos. Podendo ser semiautoritário ou semidemocrático. Nele existem eleições segundo os critérios de Schumpeter (1984), mas encontramos sérios limites aos direitos civis e uma camada delgada de civis com limitados poderes políticos, muitas das vezes ofuscados pelos militares.

Ottaway (2003) desenvolveu uma teoria a respeito de regimes políticos ditos semiautoritários. Países como o Egito, Azerbaijão, Venezuela, Senegal e Croácia foram avaliados, chegando-se à conclusão que neles os regimes políticos estruturam um sistema de hibridismo institucional no qual a inclinação para o autoritarismo é mais enfática, mesmo respeitando algumas características eleitorais. Para a autora, tais países configuram sistemas ambíguos que combinam uma aceitação retórica da democracia liberal, a existência de algumas instituições democráticas formais, e respeito por uma limitada esfera de direitos civis e políticos como essencialmente iliberal ou sempre com traços autoritários. Averigua que em sistemas ditos semiautoritários não encontramos democracias imperfeitas 
lutando em direção ao aperfeiçoamento e consolidação, mas regimes determinados a manter a aparente democracia colocando de fora os riscos políticos que a livre competição ocasiona (OTTAWAY, 2003, p. 3-27). Regimes políticos semiautoritários apostam em sistemas eleitorais da democracia. Mantêm eleições regulares e multipartidárias, permitem o funcionamento do parlamento, direitos civis e políticos (limitados), formas de associações e uma imprensa sem uma censura estatal operando, mas não consolida, e nem pretende consolidar, a democracia como regime.

As fases do modelo de democratização que Ottaway (2003) aponta são: 1) liberalização da sociedade civil com uma imprensa livre; 2) suporte às eleições e 3) instituições democráticas responsivas. No terceiro ponto tem o que O’Donnell (1998 e 1999) chamou de accountability horizontal. A imprevisibilidade e a falta de accountability de algumas instituições são frequentes em regimes semiautoritários, mas, também, podem ser encontradas em regimes semidemocráticos.

A semidemocracia, que é uma situação de "imperfeição" democrática, mostra como a questão da falta de accountability das instituições democráticas, apresentando sérias limitações e falhas em sua composição, leva a um tipo de regime de hibridismo institucional (MAINWARING et al, 2001). Sartori (1976, p. 61) define a condição mínima de uma definição:

Quando todas as propriedades ou características de um ser que não são indispensáveis para sua identificação são apresentadas como propriedades variáveis, hipotéticas - não como propriedades definidoras. Isso equivale a dizer que tudo o que ultrapassar uma caracterização mínima é deixado à verificação - não é declarado verdadeiro por definição.

No caso da democracia, características de algumas de suas instituições não podem deixar de ser levadas em consideração porque, caso sejam negligenciadas, não serão contempladas as condições mínimas da definição, como bem ressaltou Sartori (1976). 
A definição minimalista contemporânea da democracia tem quatro propriedades definidoras. As duas primeiras abrangem as dimensões clássicas schumpeterianas (SCHUMPETER, 1984) que influenciaram estudos como os de Przeworski et al (2000). A primeira corresponde às escolhas em eleições livres e limpas para o chefe do Executivo e o Legislativo. As eleições são um ingrediente essencial para a democracia representativa em nossa contemporaneidade. A transparência eleitoral e o accountability vertical (O’DONNELL, 1998) se mostram como elementos constantes que denotam grande avanço.

A segunda propriedade é a que diz respeito ao direito de voto, que deve ser extensivo à maioria da população adulta. A terceira propriedade leva em consideração a proteção aos direitos políticos e as liberdades civis, como a liberdade de imprensa, a liberdade de expressão, a liberdade de organização, o direito ao habeas corpus e outros que compreendem o componente liberal da democracia, aos quais o estado deve efetivamente cobrir para que exista democracia consolidada ${ }^{20}$.

Mesmo na condição na qual um governo seja escolhido em eleições livres e limpas, com amplo sufrágio, na ausência de uma efetiva garantia das liberdades civis não poderá ser tal regime político considerado democrático nos moldes da análise minimalista da democracia aqui destacada ${ }^{21}$.

20 Quando analisou a forma de exercício do poder dos governantes, Zakaria (1997 e 2003) mostrou como é limitada a democracia em seu viés eleitoral. Afirmou que o crescimento das eleições no mundo foi responsável pelo surgimento de regimes políticos caracterizados por democracias iliberais, i.e., são democracias sem o componente liberal, onde há eleições livres, mas os atores políticos eleitos falham em garantir os direitos básicos dos cidadãos.

21 The Economist Intelligence Unit definiu o conceito de democracia baseado em cinco critérios: 1. Electoral process and pluralism; 2. Functioning of government; 3. Political participation; 4. Political culture e 5. Civil liberties. Para avaliar e mensurar as democracias em mais de 160 países usou uma escala quadricotômica: 1 . Full democracies; 2 . Flawed democracies; 3. Hybrid regimes e 4. Authoritarian regimes. O Brasil ficou na $42^{a}$ posição entre as democracias imperfeitas (2. Flawed democracies) (The World in 2007, "The Economist Intelligence Unit's index of democracy", novembro de 2006). 
A quarta propriedade se destina a avaliar as autoridades eleitas no que diz respeito ao genuíno poder de governar sem que sejam ofuscados por atores políticos não eleitos, como os militares, por exemplo, que dominam nos bastidores (VALENZUELA, 1992). Se as eleições são livres e limpas, mas elegem um governo que não consegue controlar algumas das principais arenas políticas pela causa, por exemplo, dos militares fazerem tal controle ${ }^{22}$, então esse regime político não apresenta uma democracia consolidada (MAINWARING et al, 2001, p. 650-651).

Estes quatro critérios elencados são fundamentais para uma democracia sólida, sem os quais um regime não pode ser considerado democrático. A definição de democracia em sua dimensão minimalista aqui em enfoque, focaliza as regras do jogo acrescentando uma preocupação com as liberdades civis e com a genuína capacidade de exercer o poder. Nas seções seguintes destacarei algumas instituições que maculam os critérios três e quatro de nossa definição minimalista. O sistema de justiça brasileiro e a militarização da segurança pública são exemplos de falhas nas garantias de liberdades fundamentais e de efetivo exercício de mandados eleitorais.

\section{Due Process of Law x Devido Processo Legal}

Em regimes democráticos o seu componente liberal se encontra fortalecido no respeito integral aos direitos civis. No caso da Constituição brasileira de 1988, podemos encontrar tal componente em seu artigo 5ㅇ. O princípio da isonomia jurídica é o que garante a efetiva aplicabilidade

22 A militarização da Segurança Pública passa por tal (des)controle político. Apesar de termos um governo de esquerda, as ações do Presidente Lula para com os militares não mudou em nada a relação do Poder Executivo Federal com as FFAA em comparação aos outros presidentes, conservadores ou social-democratas, que o antecederam desde o início da transição, com a Nova República. O episódio atual com os controladores de vôo reforça esta tese: Em abril, no meio da crise dos controladores de vôo, resolveu o presidente Lula afagar os amotinados sargentos do controle de vôo, disse que não ia punir ninguém. Ao perceber a crise militar que produzira com a quebra de hierarquia na Aeronáutica, passou a condená-los e a elogiar os chefes da caserna. Depois mandou afastar os líderes do motim (JORNAL DO COMMERCIO, 2007). Isto é um bom indicador para analisarmos as relações civil-militares no Brasil. Os domínios reservados de antes se mantém de forma inalterada em muitas instituições coercitivas de hoje. 
da igualdade entre os homens e mulheres. Este princípio é encontrado na Constituição, mas no sistema de administração da justiça criminal do Brasil existem paradoxos quando comparados aos princípios constitucionais. A formação da cidadania no Brasil tem em sua história a construção de uma realidade que se distancia de uma sociedade de iguais. A tradição hierárquica prevalece na conjuntura estrutural da sociedade brasileira. Isso se encontra refletido no aparato de Justiça do Brasil. Destaca-se na formação jurídica brasileira, de caráter positivista - que parte de princípios jurídicos hierárquicos - um Poder Judiciário que não garante a efetividade das garantias individuais. Baseado no discurso de vários juristas, tenta adequar-se ao modelo judicial anglo-americano que tem em sua essência princípios que contradizem o modelo brasileiro (FERREIRA, 2004).

Baseado numa igualdade liberal, onde todos são iguais perante a lei, levanto algumas questões que negam, no caso brasileiro, justamente tal isonomia. Num contexto onde a cidadania se mostra marcada por uma divisão social, onde esta divisão, ou distinção é percebida pelos agentes da lei como fazendo parte de uma realidade estrutural na qual tratar de forma desigual os desiguais é "natural", encontra-se desenvolvido o aparato legal do Estado de Direito no Brasil (TEIXEIRA MENDES, 2004).

Desde o inquérito policial até o julgamento, o indivíduo é tratado conforme sua posição social dentro de uma escala de valores percebida pelos agentes estatais do aparato legal de justiça (KANT DE LIMA, 1995). Apesar do esforço de alguns juristas brasileiros em endossar uma doutrina jurídica isonômica à moda anglo-americana (FERREIRA, 2004), o que se verifica é um grande distanciamento entre um modelo hierarquizado e inquisitorial de justiça, no Brasil, e outro modelo, acusatorial refletido no modelo anglo-americano de justiça (TEIXEIRA MENDES, 2004). Este sistema nasceu e foi legitimado pela vontade popular, garantido pela democracia liberal estadunidense. No Brasil, ocorreu o inverso. O sistema 
processual foi formado, desde seus princípios, sob a égide do Estado produzido pela elite brasileira - numa perspectiva de dominação e controle da sociedade (KANT DE LIMA, 1999).

O Devido Processo Penal (Legal) é de fundamental importância para a garantia dos direitos civis de igualdade no processo jurídico de um país democrático. Em estudo comparativo com o modelo estadunidense, percebo que o devido processo legal (due process of law), ou penal, dos EUA tem características diferenciadas do modelo brasileiro. No Brasil o que prevalece é uma forma inquisitorial e hierarquizada de julgar o cidadão, onde o indivíduo é culpado até que se prove o inverso e as "malhas" sociais prevalecem como recurso jurídico (KANT DE LIMA, 1995). Nos EUA, a doutrina jurídica, que advém desde as emendas constitucionais ( $5 \underline{a}, 6^{\underline{a}}$, 7a e 14ํㅡ) da Carta Magna de 1787, adotou um sistema onde o cidadão aparece como o sujeito que solicita a presença da arbitragem estatal em suas querelas, onde o modelo é acusatorial e o indivíduo é inocente até que se prove o inverso, apesar da insistência de alguns teóricos do direito brasileiro em afirmar que os modelos são convergentes (FERREIRA, 2004).

O sistema jurídico estadunidense teve sua construção e consolidação legitimada pela vontade popular. Este sistema teve como base a democracia e a garantia das liberdades individuais. Já o modelo do sistema processual criminal brasileiro, foi baseado num contexto de dominação e controle sob a população. Observando estes pontos, o direito no Brasil não aparece como sendo legitimado pelo meio social, mas sim por grupos minoritários que cerceiam e dominam pelo saber e pelo controle social (FERREIRA, 2004, p. 4). O due process of law do sistema de administração da justiça criminal nos EUA, foi selecionado como modelo de comparação dos aparatos de justiça em relação ao Poder Judiciário brasileiro, na tradução do Devido Processo Legal, mostrando que, apesar do mesmo significado, ambos os modelos são antagônicos. 
A tradição popular do due process of law, que prima pela participação popular nos meios de administração de conflitos, endossa o espírito democrático na regência das relações pessoais cíveis e criminais. O Direito Criminal brasileiro tem como herança a tradição processual portuguesa, fundamentada no Direito Eclesiástico que vigorou na Península Ibérica e deslocou-se para o Brasil no processo colonizador. Na Constituição Republicana de 1891, o rompimento ideológico e político se fez colocando os dois subsistemas jurídicos, o Direito Processual Criminal e o Direito Constitucional, numa nova roupagem republicana. Mas, o sistema processual criminal do Brasil manteve-se tradicional. O modelo inquisitorial desse sistema se mantém até hoje (FERREIRA, 2004, p. 5-6).

A ideologia liberal constitucional, isonômica, entra em contradição com o modelo jurídico brasileiro. Tomando como exemplo a questão do 'julgamento justo', percebo que a essência básica dos direitos civis não é contemplada no mecanismo de tutela jurisdicional do Devido Processo Legal (Penal) nacional. A categorização social está implícita na forma de administrar conflitos do Poder Judiciário. As ditas "malhas" sociais prevalecem como forma de resolução de conflitos no modelo brasileiro.

A cláusula do due process of law nos EUA, está garantida nas 5aa $6^{2}$, 7므 e 14a emendas à Carta Magna. Garantindo o acesso à tutela jurisdicional do Sistema de Justiça Criminal estadunidense. Tal acesso representa um direito das pessoas acusadas por algum ato ilícito ou criminoso, onde tais pessoas se sintam ameaçadas em seu direito à liberdade, à vida ou à propriedade em face do Estado. Quando o acusado, alegando não ter culpa (not guilty) das acusações que lhe foram imputadas, solicita o julgamento pelo Tribunal do Júri (Trial by Jury), fica, a partir desse momento, instaurado o processo. É na solicitação do acusado que há a instauração oficial do processo e é neste momento que o indivíduo exerce o seu direito de ter o Devido Processo Legal (due process of law), tendo assim, as- 
segurada a decisão isonômica e imparcial de todo o processo. Esta subjetividade constitucional leva ao livre arbítrio do acusado, pois este direito, em sua essência, se reveste de disponibilidade, isto é, de livre exercício do acusado ao due process of law, ele pode renunciar a esse direito de ser julgado pelo Trial by Jury (FERREIRA, 2004, p. 9).

As já referidas emendas constitucionais vieram consolidar as garantias civis das pessoas acusadas nos EUA. As emendas cinco e seis garantiram as pessoas acusadas o direito de não sofrerem arbitrariedades no processo de julgamento, bem como serem atores políticos ativos do seu processo:

Emenda quinta: Nenhuma pessoa será obrigada a responder por um crime capital ou infamante, salvo por denúncia ou pronúncia de um júri, exceto em se tratando de casos que, em tempo de guerra ou de perigo público, ocorram nas forças terrestres ou navais, ou na milícia, quando em serviço ativo; nenhuma pessoa será, pelo mesmo crime, submetida duas vezes a julgamento que possa causar-lhe perda da vida ou de algum membro; nem será obrigada a depor contra si própria em processo criminal ou ser privada da vida, liberdade ou propriedade sem que exerça seu direito ao processo legal regular (due process of law); a propriedade privada não será desapropriada para uso sem justa indenização (CORWIN, 1986, p. 254).

Emenda sexta: Em todos os processos criminais o acusado terá direito a julgamento rápido e público, por um júri imparcial do Estado e do distrito onde o crime houver sido cometido, distrito este que será previamente determinado por lei; a ser informado da natureza e causa da acusação; a ser acercado com as testemunhas que Ihe são adversas; a dispor de meios compulsórios para forçar o comparecimento de testemunhas de defesa e a ser assistido por advogado (CORWIN, 1986, p. 259).

A sétima emenda veio garantir o julgamento pelo tribunal do júri. Este direito deu ao acusado o atributo de renunciar em praticamente to- 
dos os crimes. Já a emenda décima quarta, de 1868, reforçou as garantias processuais, limitando mais ainda a ação arbitrária do Estado:

Emenda sétima: Nos processos segundo a common law em que o valor da causa exceder em vinte dólares, será garantido o direito ao julgamento pelo júri e os fatos julgados por este não serão reexaminados em qualquer tribunal dos EUA, a não ser de acordo com as regras da common law.

Emenda décima quarta: Nenhum Estado fará ou executará qualquer lei restringindo os privilégios ou imunidades dos cidadãos dos Estados Unidos; nem privará qualquer pessoa da vida, da liberdade ou propriedade, sem o processo legal regular (due process of law); nem negará a qualquer pessoa, dentro de sua jurisdição, a igual proteção das leis. (CORWIN, 1986, p. 298)

Nos EUA, como processo de uma tradição advinda com a Common Law britânica, a expressão due process of law serviu de base para a construção e defesa dos direitos civis, principalmente aqueles referentes às garantias a um julgamento processual justo. Dessa forma, a expressão due process of law se concretizou como fórmula restritiva, limitando os atos do Congresso.

Os procedimentos que regulam a administração da Justiça Criminal nos EUA apresentam pontos e características que fortalecem o seu conteúdo individual, i.e., a formatação dos procedimentos tem como foco principal a defesa do indivíduo perante os possíveis abusos do Estado (FERREIRA, 2004).

Há no modelo anglo-americano um procedimento para administração da culpabilidade do acusado, onde um acordo pode ser firmado entre as partes, construindo, dessa forma, uma verdade, não necessariamente a "verdade real". Nesse modelo que "fabrica" a verdade, o que prevalece é a verdade construída entre as partes.

Sendo assim, o procedimento de Justiça Criminal dos EUA começa com a detenção do suspeito. Quem faz tal tarefa é a polícia. Esta faz parte do Sistema de Justiça americano. Como a polícia faz parte do Judiciário, 
tem maior autonomia para a aplicação dos procedimentos legais. Mas, depois do suspeito preso, a polícia deve ir à autoridade legal para obter a permissão para manter detida a pessoa em custódia. Ainda existe a possibilidade de a polícia ignorar casos que ela entenda como irrelevantes, ou ainda fazer uma advertência ao infrator sem conduzi-lo sob custódia. Em casos graves, é comum a polícia requerer a instauração de uma acusação formal pela Promotoria (District Attorney).

A promotoria é a ponte que liga a polícia e os tribunais. Segundo Neubauer (1988, p. 27-28) ela é a figura mais importante do sistema criminal estadunidense. Coordena as acusações criminais que serão executadas e influencia no procedimento de fixação da fiança, no processo de argumentação da barganha (Plea Bargain) e, muitas das vezes, na própria sentença. Há ampla autonomia da Promotoria no processo que formaliza a acusação, decidindo, também, quais as acusações criminais que devem ou não ser arquivadas.

O primeiro encontro do acusado com os tribunais é o Initial Appearance. $\mathrm{O}$ juiz o cientifica do seu direito em permanecer calado, do direito a um advogado, do direito à fiança e do direito a uma audiência preliminar, se for aplicável ao seu caso. Aqueles que foram acusados por crimes graves (Felony) o Initial Appearence é apenas formal, pois os acusados desse tipo de crime não podem entrar na discussão de determinação de culpa (guilty) ou não culpa (not guilty). Já para os acusados de crimes leves (Misdemeanor), o Initial Appearence pode vir a ser o único encontro com o Tribunal.

A audiência preliminar (Preliminary Hearing) aparece como procedimento que antecede, ou não, o envolvimento com o Grand Jury (Júri de Acusação). Nesse período há o exame preliminar que tem como propósito proteger o acusado contra a instauração de processo não comprovado. O juiz tem, pela primeira vez, a oportunidade de avaliar as forças das evidências contra o acusado. Ali, o promotor deve mostrar a existência 
de causa, ou causas, provável para efetivar a crença de que o acusado cometeu um crime grave (Felony). No entanto, as exigências de evidência acusatória são menos rígidas do que quando for contemplada no Tribunal do Júri. Vai depender do juiz a convocação do Júri de acusação.

Ponto de fundamental importância desse modelo acusatório dos EUA é a Plea Bargaing. Tal procedimento consiste numa audiência préprocessual que ocorre entre o defensor do acusado e o promotor. Este tem duas funções: primeiro, estabelece a acusação com suas causas prováveis e, em seguida, notifica e participa nas deliberações a respeito da concessão de fianças. Esta negociação, o Plea Bargaing, dá-se da seguinte maneira: o promotor e o defensor se reúnem com o juiz na sala do tribunal onde se dedicam às discussões que tem o intuito de concluir um acordo a respeito da culpabilidade do acusado. Há uma grande discussão sempre tentando preservar o acusado, seguindo uma forma conclusiva que seja ótima (equilíbrio) para o acusado e o acusador. Somente com a recusa do acusado, conforme o que foi decidido no Plea Bargaing, no que tange ao resultado é que será instituído o júri de acusação (Grand Jury). Não obstante, negociações futuras podem ocorrer.

Esse expediente utilizado no modelo de justiça americano consolida uma função bilateral entre o Poder Judiciário e a sociedade civil. Também mostra uma forma maleável na construção da verdade. O Plea Bargaing é um recurso utilizado pela promotoria onde ela pode oferecer algumas concessões em troca da aceitação do acusado de sua culpa. Numa discussão pode-se chegar a uma tipificação legal do ato cometido. Este pode ser reduzido a um delito de menor potencial, assegurando uma redução de pena, caso o acusado aceite a deliberação da promotoria.

Como foi dito, o Plea Bargaing é um mecanismo pré-processual. A formalização do processo é iniciada pelo promotor e segue três outros mecanismos. O primeiro consiste num documento onde o promotor de- 
clara uma acusação formal. Nela constam os fundamentos da violação, os argumentos e as evidências que sustentam a acusação. $\mathrm{O}$ juiz decide se há "causa possível" para instaurar o processo. Quando isso acontece passa para a incumbência do Grand Jury (Júri de Acusação) que recebe o documento elaborado pelo promotor. Com o convencimento do Júri de acusação há a formalização final da acusação passando, dessa forma, o acusado a ser julgado pelo Tribunal do Júri.

Apresentado pela doutrina jurídica como um dos mais importantes direitos fundamentais, o direito ao Júri de Sentença (Trial by Jury) que representa o direito de ser julgado em um tribunal por seus pares é uma garantia constitucional dos EUA concedida aos acusados de violar a lei criminal (FERREIRA, 2004).

A formação do Processo Criminal na tradição jurídica brasileira obteve formas do Direito Canônico que tiveram forte impacto na formação do processo escrito e, também, no próprio sistema que se apresenta com características inquisitoriais. Como, também, o sistema acusatorial, fundado no Direito Romano. Com forte caráter estatal o procedimento jurídico brasileiro quanto à questão do Processo Penal, se formou num contexto no qual o indivíduo aparece "espremido" pelo saber positivista do Estado.

O sistema jurídico-inquisitorial brasileiro tem este caráter desde o período imperial. O Processo Criminal de 1841 subordinou a formação da culpa ao procedimento inquisitório não correspondendo a um modelo acusatorial (FERREIRA, 2004, p. 51).

Grande parte dos elementos característicos do sistema inquisitório está implícita em nosso ordenamento jurídico atual. O procedimento escrito, o sigilo do inquérito, a iniciativa de instrução do juiz e a busca da verdade real, são pontos que revelam este caráter.

No sistema acusatório, que está refletido no modelo anglo-americano exposto linhas acima, o acusado é presumido inocente. Isso garante direitos 
civis básicos respeitados. Já o sistema inquisitorial, característico do Direito brasileiro, supõe a culpabilidade do acusado, tendo total controle na busca e coleta dos indícios e provas. O modelo anglo-americano se preocupa com o interesse individual que não pode ser lesado, o modelo brasileiro se preocupa com o interesse público lesado pelo delito. Essa corrente de pensamento jurídica sustenta a idéia de um Estado paternalista, defensor do interesse público se opondo ao interesse individual. Desenvolveu-se de forma contundente no período monárquico no Brasil e influenciou diretamente a tradição jurídica brasileira até nossos dias (FERREIRA, 2004).

O argumento da liberdade individual como direito inalienável era usado com pouca ênfase, não tinha a força que the era característica na tradição anglo-saxônica. Não o favorecia a interpretação católica da Bíblia, nem a preocupação da elite com o Estado Nacional. Vemos aí a presença de uma tradição cultural distinta, que poderíamos chamar de ibérica, alheia ao iluminismo libertário, à ênfase nos direitos naturais à liberdade individual. Essa tradição insistia nos aspectos comunitários de vida religiosa e política, insistia na supremacia do todo sobre as partes, da cooperação sobre a competição e o conflito, da hierarquia sobre a igualdade (CARVALHO, 2002, p. 51).

A perspectiva do "ideal liberal" não encontrou espaço no sistema processual penal brasileiro. Depois de proclamada a República e com a promulgação da Constituição de 1891, a manutenção da organização judiciária e policial do período imperial, caracterizado por profunda hierarquia de tratamento, foi mantida. Essa organização se converteu nos atuais Códigos Penal e Processual Penal brasileiros. Mas, no paradoxal modelo brasileiro, o princípio da Constituição de 1988 é a isonomia, ou seja, a igualdade jurídica constitucional garante o devido processo legal em moldes não hierárquicos.

Como se observa, há um sério problema normativo quanto à questão do devido processo legal (due process of law). A Constituição brasileira 
de 1988 concebe a sociedade em princípios igualitários, todos são iguais perante as leis. Já o processo de inclusão judiciária é hierarquizado, prevalecendo o tratamento desigual aos cidadãos.

Alguns teóricos do direito no Brasil admitem a compatibilidade entre os princípios constitucionais e o devido processo legal na formalização do Direito Criminal brasileiro. Acordando com a posição majoritária dos juristas, o Devido Processo Penal, fundado na garantia constitucional, no tópico dos Direitos e Garantias individuais, que, em tese, são direitos oponíveis ao Estado, afirma a Constituição de 1988: Art. 5ํo , LIV, Ninguém será privado da liberdade ou de seus bens sem o devido processo legal (grifo meu).

Tais juristas, que representam o discurso positivista, traduzem isso como sendo o due process of law dos EUA, simbolizado nas emendas à Constituição estadunidense (FERREIRA, 2004, p. 59-60).

O discurso majoritário dos juristas endossa uma posição de Estado de Direito Democrático por parte do devido processo legal no que tange ao Processo Penal. Mas, o que se observa é que o indivíduo acusado, o principal ator político dessa "peça", em nenhum momento aparece como o agente dotado de direitos que vem solicitar o aparato jurídico para sua defesa, como reza o due process of law nos Estados Unidos. Esse aparato vai sendo imposto ao réu, pois o seu representante, o Ministério Público, é quem toma todas as providências na demanda jurídica. A perspectiva do coletivo supera a do indivíduo.

O Estado assume o monopólio da administração da Justiça. O ofendido e o Ministério Público, ambos titulares da ação penal, são os principais atores no âmbito criminal. O acusado não tem escolha. O Código Penal Brasileiro expõe as prerrogativas do Estado e do ofendido (acusador), inexistindo, dessa forma, a isonomia necessária para o estabelecimento do devido processo legal de um efetivo Estado de Direito Democrático: 


\section{Código Penal Brasileiro}

Art. 100. A ação penal é pública, salvo quando a lei expressamente a declara privada do ofendido.

$\S 1^{\circ}$ : A Ação Pública é promovida pelo Ministério Público, dependendo, quando a lei o exige, de representação do ofendido ou de requisição do Ministro da Justiça.

$\S 2^{\circ}$ : A ação de iniciativa privada é promovida mediante queixa do ofendido ou de quem tenha qualidade para representá-lo.

$\S 3^{\circ}:$ A ação de iniciativa privada pode intentar-se nos crimes de ação pública, se o Ministério Público não oferece a denúncia no prazo legal.

$\S 4^{\circ}:$ No caso de morte do ofendido ou de ter sido declarado ausente por decisão judicial, o direito de oferecer queixa ou de prosseguir na ação passa ao cônjuge, ascendente, descendente ou irmão.

A permanente ausência do acusado no processo penal vai fortalecendo, cada vez mais, o caráter inquisitorial do sistema. $\mathrm{O}$ ente acusado não tem papel ativo em nenhum momento:

Código de Processo Penal Brasileiro

Art. 24. Nos crimes de ação pública, esta será promovida por denúncia do Ministério Público, mas dependerá, quando a lei o exigir, de requisição do Ministro da Justiça, ou de representação do ofendido ou de quem tiver qualidade para representá-lo.

Art. 30. Ao ofendido ou a quem tenha qualidade para representá-lo caberá intentar a ação privada. ${ }^{23}$

No ingresso do indivíduo na relação processual penal no Direito Brasileiro, tem-se constrangida a ação do acusado, pois o direito de iniciar o processo é do ofendido ou acusador. Os pressupostos processuais das Condições de Ação Processual não permitem a autonomia do ente acusa-

23 As referências aos Códigos Processual Penal e Penal estão sob o Título III - DA AÇÃO PENAL e Título VII - DA AÇÃO PENAL, respectivamente. 
do. A primeira condição da ação (Legitimatio ad Causam), determina que somente tem o direito da ação o ofendido ou o Ministério Público, que a lei descreve como titular desse direito. A segunda condição é denominada "Interesse de Agir. Assim, tem interesse de agir aquele que necessita ir a juízo para satisfazer uma pretensão". A terceira condição é a chamada Possibilidade Jurídica. Nesta, a ação só pode ser exercida se houver previsão legal em tese da providência que o autor solicita na hipótese (FERREIRA, 2004, p. 65-66).

O que se observa então, é que a maioria dos requisitos que administram e organizam a propositura da demanda penal são exigências que, geralmente, recaem sobre o ofendido. Este é o detentor do poder de mover a máquina estatal para que esta dê resolução ao conflito. Uma visão unilateral, onde a isonomia entre as partes, acusada e acusadora, não existe.

No entanto, há exceções a tais regras. Não se descarta, no procedimento processual penal brasileiro, a possibilidade de o réu propor uma ação penal no intuito de fazer valer sua defesa. Configurando, dessa forma, ao mesmo tempo como ofensor e autor, mas tendo que obedecer aos preceitos processuais exigíveis a qualquer ação penal. Essas ações são chamadas de ações declaratórias no processo penal.

A ação declaratória revela a existência, ou não, de um direito. São elas: Habeas Corpus Art. 648, Código de Processo Penal, fundado em pedido de atipicidade do fato imputado, seja na ação penal ou no inquérito policial. Habeas Corpus, Art. 648, VII, Código de Processo Penal, para que seja extinta a punibilidade, em declaração elaborada pelo juiz. E o Habeas Corpus preventivo. Além de que, no caso das ações constitutivas, reconhecer pena a ser cumprida no estrangeiro e a revisão criminal.

Percebe-se que tais procedimentos vêm garantir as liberdades do indivíduo acusado. Mas, é importante frisar que tais procedimentos não representam a regra geral.

Outra exceção à regra aparece na Lei 9.099/95, que instituiu o Juizado Especial Criminal. Tal Lei lembra o procedimento do Plea Bargain 
dos EUA. Sofreu influência das tradições processuais penais do sistema de administração da Justiça estadunidense. Esta Lei compete às questões relacionadas aos delitos de menor potencial ofensivo. Estabelece, em seu artigo 72, a possibilidade de conciliação, uma negociação entre as partes (FERREIRA, 2004, p. 67-68).

O Juiz ou conciliador deve esclarecer o autor do fato e a vítima sobre as vantagens que a conciliação traz para ambos. A vítima obtém um título executivo no juízo civil, o que Ihe dá a possibilidade de reparação, de imediato, do dano sofrido, e o autor do fato, em razão do acordo, não será condenado, nem sequer será processado pela infração cometida (BATISTA; FUX, 1998, p. 314).

Todavia, a regra no devido processo penal brasileiro firma o direito do titular da ação penal ao ofendido ou seu representante ou, ainda, ao Ministério Público como sendo os atores políticos que terão a prerrogativa de pleitear, perante o Estado, a tutela jurisdicional, como foi colocado acima nos artigos 24 e 30 do Código de Processo Penal. O réu acusado tem seu direito ao devido processo penal respaldado no Art. 5o, LV, da Constituição Federal, que garante o contraditório e a ampla defesa. Mas, a formalização do processo judicial só acontece com a citação do réu pelo acusador, Art. 394 do Código de Processo Penal, onde só apresentará sua defesa, no caso do acusado, três dias depois do interrogatório (Defesa Prévia, Art. 395 do Código de Processo Penal). Apesar do discurso sustentado por diversos juristas (FERREIRA, 2004) da prevalência da isonomia, essa dogmática é contestada.

Percebe-se claramente que os dois modelos são antagônicos. O modelo brasileiro se mostra ambíguo e não contempla o aspecto liberal que garante direitos de cidadania. Dessa forma, o Devido Processo Legal no Brasil não contempla direitos civis, i.e., não contempla, segundo a teoria aqui colocada, uma democracia consolidada.

Outro aspecto importante para a análise conceitual minimalista da democracia diz respeito à influência dos militares no âmbito político. Isso, além de fragilizar o poder daqueles que foram eleitos pelo povo, macula 
os direitos civis, pois a segurança pública, que é um bem público, passa a ter demandas militares, ou seja, prevalecendo a hierarquia em vez do justo em muitas de suas instâncias. A próxima seção detalha o que entendo como limite ao critério quatro da definição aqui exposta.

\section{A militarização ${ }^{24}$ da segurança pública: Estado x cidadãos (a supremacia militar na segurança pública, um legado autoritário)}

Ponto importante para a efetividade da democracia é o que diz respeito à segurança dos indivíduos. A segurança é direito civil e social e consta nos artigos 5으 e 6으 da Constituição Federal de 1988. Em seu artigo 144 temos disponibilizado o seu ordenamento. A estrutura de Segurança Pública brasileira, que deveria ser de natureza civil e com fins de defender os interesses dos cidadãos brasileiros em quaisquer circunstâncias, se preocupa mais com a defesa dos interesses do Estado que da cidadania, onde o processo de militarização dessas instituições é a prova desse hiperdimensionamento do Estado em relação aos cidadãos ${ }^{25}$.

A estrutura do aparelho policial se manteve praticamente o mesmo do regime autoritário. No processo de formulação da Constituição, foram mantidas prerrogativas militares ${ }^{26}$ em atividades de segurança interna, como

24 "Entenda-se por militarização o processo de adoção e uso de modelos militares, conceitos e doutrinas, procedimentos e pessoal, em atividades de natureza civil. A militarização é crescente quando os valores do Exército se aproximam dos valores da sociedade. Quanto maior o grau de militarização, mais tais valores se superpõem" (ZAVERUCHA, 2006).

25 "A Constituição de 1988 cometeu o erro de reunir em um mesmo Título V (Da Defesa do Estado e das Instituições), três capítulos: o Capítulo I (Do Estado de Defesa e do Estado de Sítio), o Capítulo II (Das Forças Armadas) e o Capítulo III (Da Segurança Pública). Nossos constituintes não conseguiram se desprender do regime autoritário recém-findo, e terminaram por constitucionalizar a atuação de organizações militares em atividades de polícia (Polícia Militar) e defesa civil (Corpo de Bombeiros), ao lado das polícias civis. As policias continuaram constitucionalmente, mesmo em menor grau, a defender mais o Estado que o cidadão" (ZAVERUCHA, 2005, p. 72-73).

26 "Referem-se àquelas áreas onde, desafiados ou não, os militares, como instituição, assumem ter adquirido o direito ou privilégio, formal ou informal, de governar tais áreas, de ter um papel em áreas extramilitares dentro do aparato do Estado, ou até mesmo de estruturar o relacionamento entre o Estado e a sociedade política ou civil" (STEPAN, 1988, p. 93). 
o policiamento (Polícias Militares) e defesa civil (Corpo de Bombeiros). As PMs dividindo com os policiais civis a administração dos conflitos sociais.

Antes do período em que os militares estiveram no governo (1964-1985), as Polícias Militares tinham papel secundário em questões de segurança:

Ficavam aquarteladas nas principais capitais do país e não faziam o patrulhamento das ruas. As polícias não-militares tinham o papel primordial. Cabia às mesmas, tanto o papel ostensivo (incluindo o trânsito e a segurança de dignitários), como o investigativo e, pela atuação do Delegado de Polícia investido de função jurisdicional, realizar a instrução criminal dos processos sumários (ZAVERUCHA, 2004, p. 56).

Com o advento do regime de exceção, no auge da repressão política, as Polícias Militares ascenderam à frente das Guardas Civis. As PMs passaram a crescer no âmbito da sociedade fazendo o policiamento ostensivo e a manutenção da ordem pública, incluindo, também o controle do tráfego de veículos. O Delegado perdeu a prerrogativa jurisdicional na realização das instruções dos processos sumários (ZAVERUCHA, 2004, p. 56).

O Decreto-Lei federal no 1.072 de 30 de dezembro de 1969, extinguiu as Guardas Civis no Brasil, suas atribuições passaram para as PMs. Subordinadas ao Exército através da Inspetoria Geral das Polícias Militares, ficaram responsáveis, de forma isolada, pelo policiamento preventivo e ostensivo (MARIANO, 1998). As PMs foram institucionalizadas pelo Exército no intuito de combater os conflitos sociais indesejáveis, vinculando as forças de segurança aos interesses políticos castrenses. Os Decretos n. 667 e 88.777 regularam a atuação das $\mathrm{PMs}^{27}$. Os serviços de informações das PMs (P-2) ficaram integrados ao Exército e o seu regulamento disciplinar similar ao do Exército ${ }^{28}$.

27 Por esta regra, cabe as PMs "executar com exclusividade, ressalvadas as missões peculiares das Forças Armadas, o policiamento ostensivo, fardado, planejado pelas autoridades competentes, a fim de assegurar o cumprimento da lei, a manutenção da ordem pública e o exercício dos poderes constituídos" (ZAVERUCHA, 2004, p. 57).

28 Bem como o Corpo de Bombeiros os policiais militares passaram a ser regidos pelos novos Códigos Penal Militar e de Processo Penal Militar (Decretos-Lei no 1001 e 1002, respectivamente) editados em 21 de outubro de 1969. 
Com a formação da nova Constituição, em 1988, o aparato policial criado no ancien regime foi tornado constitucional, ou seja, a intervenção castrense nos assuntos civis de segurança pública permaneceu na constituição dita cidadã. O que prevalece é uma polícia preocupada com a defesa do Estado e não com a segurança individual ${ }^{29}$.

No atual quadro de atuação das polícias, num arranjo institucional onde a Polícia Civil e a Polícia Militar são atores não-cooperativos, a inoperância e o baixo accountability são fatores difíceis de serem revertidos. O maior problema está na questão crucial de nenhuma das duas realizar o ciclo completo de polícia. Este caracterizado pela prevenção, patrulhamento das ruas, investigação e indiciamento do indivíduo à Justiça. Na verdade, ambos fazem metade do papel de polícia. Na segurança pública brasileira isto é catastrófico, pois como atores políticos não cooperativos as duas partes às quais cada uma é competente não se complementam. Isso gera uma inoperância que leva toda a sociedade a ficar praticamente "órfã" de segurança. A integração das polícias ou a desmilitarização podem ser fatores de avanço na garantia de direitos fundamentais ${ }^{30}$.

No art. 144 da Constituição Federal de 1988, em seu § 7으, tem-se: "A Lei disciplinará a organização e o funcionamento dos órgãos responsáveis pela segurança pública, de maneira a garantir a eficiência de suas ati-

29 Um dos pontos fundamentais desse legado é o que diz respeito à tortura. No período militar era matéria de ensino e prática rotineira dentro da máquina militar de repressão política. A Segurança Pública vista como o ponto máximo tinha uma concepção absolutista da segurança da sociedade. Esta concepção coloca o país acima de tudo, valendo, dessa forma, todo o tipo de mecanismo para protegê-lo, incluindo aí a tortura, "contra a pátria não há direitos" (GASPARI, 2002, p. 17).

30 "Em dezembro de 2005, foi inaugurada no Centro de Belo Horizonte a 1a Região Integrada de Segurança Pública, que reúne no mesmo espaço físico o comandante do Policiamento da Capital e o delegado-chefe do Departamento de Polícia Civil, além de cerca de cem integrantes das duas polícias. Mais que dividir o mesmo prédio, ambas compartilham um mesmo banco de dados, o Registro de Eventos de Defesa Social, que armazena os boletins de ocorrência. (...) A integração é apontada como um dos principais fatores para a queda da criminalidade no Estado. Segundo a Secretaria de Defesa Social, entre 2005 e 2006 o número de assaltos a banco caiu 37\%, e o de roubo de carga 50\%. Na região metropolitana de Belo Horizonte, as ocorrências de crimes violentos, que em 2003 somaram 1.463 casos para cada grupo de 100 mil habitantes, fecharam o ano passado em 962 casos por grupo de 100 mil." (MASSON; AZEVEDO; FERNANDES, 2007, p. 86). 
vidades". Até o momento esta lei não foi regulamentada (ZAVERUCHA, 2004 , p. 58). Cada polícia tem sua legislação específica e interpreta a sua maneira o seu próprio papel. Isso gera choque de competências.

Além do problema institucional gerado por tal arranjo, temos a Polícia Militar tendo maior espaço na questão da segurança pública. O Poder Executivo, pressionado pelas forças castrenses, cada vez mais atribui maiores prerrogativas à segurança interna às PMs. Este processo de militarização da segurança pública vem crescendo desde a implantação da "Nova República".

Os perigos da militarização são os mais diversificados:

Aumenta e fortalece as prerrogativas em um contexto de debilidade do controle civil; expõe as Forças Armadas a casos de corrupção, danificando a eficiência da instituição bem como sua legitimidade; desprofissionaliza os militares que mesmo em nome da Segurança Nacional passam a fazer papel de polícia incluindo os serviços de inteligência militares, e forma-se um ciclo vicioso: verbas que poderiam ser usadas para reequipar as forças policiais são direcionadas para as Forças Armadas (ZAVERUCHA, 2005, p. 128).

Na Constituição Federal de 1988, as cláusulas relacionadas com as Forças Armadas, policiais militares estaduais, sistema judiciário militar e de segurança pública em geral, permaneceram praticamente idênticas à Constituição autoritária de 1967/69. As Forças Armadas tiveram papel de grande importância na manutenção de suas prerrogativas, pois nomearam 13 oficiais superiores que fizeram lobby pelos seus interesses no período de redação daquela carta (ZAVERUCHA, 1998).

Eram oito as comissões de trabalho responsáveis pela elaboração da Carta Constitucional. A Comissão de Organização Eleitoral Partidária e Garantia das Instituições, presidida pelo então senador Jarbas Passarinho - o mesmo que participou do Al-5, em 1968, que fechou o Congresso Nacional - ficou encarregada dos capítulos ligados às Forças Armadas e à Segurança Pública (ZAVERUCHA, 2005, p. 60). 
O deputado Ricardo Fiúza ficou responsável pela subcomissão de Defesa do Estado, da Sociedade e de sua Segurança. Apoiou firmemente as demandas militares nos debates constitucionais, chegando a rejeitar a tentativa de alguns congressistas de criar o Ministério da Defesa, bem como trabalhar, também, contra a tentativa de se dar fim ao controle do Exército sobre as Policias Militares Estaduais. Optou por favorecer a autonomia das Forças Armadas mantendo o controle parcial do Exército sobre as PMs, alegando para isso que o governo necessitaria de todas as suas forças para controlar contestadores da ordem social (ZAVERUCHA, 2005, p. 60-61).

O resultado disso foi uma constituição com fortes prerrogativas para os militares, isso ficou configurado no caráter ambíguo da carta magna. Artigos liberais de um lado e de outro, artigos com forte inclinação à ingerência militar. Analisando o artigo 142, percebe-se isso de forma bastante dimensionada:

As Forças Armadas, constituídas pela Marinha, pelo Exército e pela Aeronáutica, são instituições nacionais permanentes e regulares, organizadas com base na hierarquia e na disciplina, sob a autoridade suprema do Presidente da República, e destinam-se à defesa da Pátria, à garantia dos poderes constitucionais e, por iniciativa de qualquer destes, da lei e da ordem (Constituição Federal de 1988).

Como garantidores da lei e da ordem internas, a qualquer momento esse ator político (Forças Armadas) pode interferir em assuntos de segurança interna que, em democracias plenas, jamais existiria. Tal prerrogativa aparece como sendo de alta intensidade, pois a constituição encarrega os militares de responsabilidade principal na garantia da lei e da ordem interna, outorgandoIhes uma grande margem de decisão que lhes permite determinar quando e como devem cumprir com suas obrigações (STEPAN, 1988, p. 525).

Lei e ordem podem ter várias conotações, a interpretação da ordem interna por parte dos militares pode estar permeada por uma série de estímulos ideológicos. A garantia dessa ordem, ou dos poderes constitucio- 
nais, quando da solicitação de qualquer um dos três poderes (Executivo, Legislativo ou Judiciário) da República, pode não ser levada em consideração por parte dos militares. Se os três poderes não acharem conveniente ou necessária a intervenção dos militares para manter a ordem interna, mas estes, baseados na constituição - que lhe dá plenos poderes de garantidores da lei e da ordem interna - , acharem que devem intervir, prevalecerá a vontade castrense, daqueles que estão armados e respaldados constitucionalmente (ZAVERUCHA, 1998, p. 128). Por conseguinte, a autoridade suprema do presidente da República perante os militares pode ter efeito nulo, sobretudo quando estiver fraco politicamente. O artigo 142, também não especifica que tipo de lei é a que está inserida nele, se de ordem constitucional ou ordinária, e a ordem também não está especificada, se tem caráter social, político ou moral. Este artigo é muito vulnerável, fazendo com que uma intervenção militar em assuntos internos ocorra ao bel prazer dos militares.

Depois do incidente provocado pela intervenção militar, solicitada por um juiz do terceiro Distrito de Volta Redonda, na Companhia Siderúrgica Nacional (CSN), que resultou na morte de três operários da estatal (ZAVERUCHA; MELO FILHO, 2004, p. 781), o Congresso Nacional aprovou, em 23 de julho de 1991, uma lei complementar, de número 69, que veio restabelecer a cláusula constitucional de 1967/69. Esta concedia apenas ao Executivo federal o direito de pedir a intervenção militar em assuntos de segurança interna. $\mathrm{O}$ artigo 142 nivela os três poderes e não especifica nenhuma hierarquia dentro deles ou entre eles.

Na primeira versão do artigo 142 os militares perderam o papel de guardiões da lei e da ordem. O ministro do Exército, General Leônidas Pires Gonçalves, ameaçou zerar todo o processo de redação constitucional. Temerosos, os constituintes acharam por bem ceder e o papel de garantidores da lei e da ordem voltou a aparecer na nova versão do referido artigo. Para que tal capitulação ficasse dourada, o Congresso 
optou por conceder tanto ao Judiciário quanto ao Legislativo o direito de pedir a intervenção das Forças Armadas em assuntos domésticos. Ao não especificar que instância do Judiciário poderia convocar os militares, a Constituição nivelou os poderes do Supremo Tribunal Federal ao de um juiz iniciante em uma pequena cidade. Do mesmo modo, equiparou o presidente do Congresso a um parlamentar em seu primeiro mandato (ZAVERUCHA, 1998, p. 128-129).

A lei complementar no 69, ao invés de inferir maior controle civil sobre os militares, deu maiores prerrogativas aos mesmos, pois retomou sua essência do período de exceção, concentrando as decisões no Poder Executivo. Com um presidente nas mãos dos castrenses, a intervenção militar em assuntos políticos fica mais iminente (vide nota 23).

Outro aspecto importante do processo de militarização da segurança pública diz respeito a formação do Ministério da Defesa (MD). Em 2000, o orçamento do Ministério da Defesa foi o segundo maior da União ${ }^{31}$.

De um total de $R \$ 1,8$ bilhão que a Defesa tinha para investir, a pasta usou $R \$ 1,7$ bilhão, o equivalente a $94 \%$ do previsto. Em valores absolutos, a Defesa investiu mais que qualquer uma das pastas da área social e só perdeu para o Ministério dos Transportes, que usou $R \$ 2,5$ bilhões, 59\% do que poderia ter sido usado (ZAVERUCHA, 2003, p. 403).

Seguindo esta linha, o Ministério da Defesa surge como um ponto de veto militar importante nas relações civil-militares. Segundo Oliveira e Soares (2000), o MD foi criado na tentativa de colocar os assuntos militares sobre influência e controle dos civis. Depois de um longo processo de análise, que durou todo o primeiro mandato de FHC, em julho de 1999 foi criado o MD, após um período de cinco meses em caráter extraordinário - onde conviveu com os demais ministérios militares, os quais foram extintos posteriormente. A criação do MD deu-se por medida provisória, com a participação do Congresso sendo praticamente inexistente. A

31 No atual quadro orçamentário os gastos com militares estão em terceiro lugar. 
participação da comunidade acadêmica foi irrisória (OLIVEIRA; SOARES, 2000). No processo de construção de tal ministério a atuação dos militares, com sua representação no EMFA (Estado Maior das Forças Armadas), foi decisiva e sua estrutura se mostra, ainda hoje, bem militarizada. Os ministros civis que "comandam" o MD são ofuscados por vontades de generais (alguns deles da reserva) que demandam poder nos bastidores.

A fragilidade institucional do ministro da defesa é bem acentuada. Nos EUA a posição institucional do Ministro da Defesa é fortalecida. No Brasil, aquele modelo foi criticado pelos militares, que alegaram peculiaridades tais, que seria impossível suprir o modelo estadunidense. O ministro da defesa se dirige diretamente aos comandantes de cada força, já que o Ministério da Defesa não possui um Estado-Maior Geral forte que comande a Marinha, o Exército e a Aeronáutica. Esse Estado-Maior Geral, denominado no Brasil de Estado-Maior da Defesa, tem função de assessoria e segue uma especificidade militar. $\mathrm{O}$ ministro da defesa termina não participando do processo de ordenança das operações. Já no modelo dos EUA, o secretário de defesa controla pessoalmente os comandos (LOPES, 2001).

No que tange à criação do MD, ali não houve nenhuma intenção de efetivar controle civil sobre os militares. Na verdade, o que existiram foram interesses externos da política brasileira:

Desde 1995, quando FHC anunciou seu propósito de criar o Ministério da Defesa, o plano vinha sendo tocado lentamente. De repente, os EUA anunciaram que a Argentina seria seu sócio extra-OTAN. Logo a seguir, o então presidente Menem declarou, em 17 de agosto de 1997, que o lugar dos países latino-americanos no Conselho de Segurança da ONU deveria ser rotativo, e não fixo para o Brasil, como desejava a diplomacia verde-amarela (Zaverucha, 2000). De pronto FHC reagiu. Durante a reunião do Grupo do Rio em Assunção, em 24 de agosto de 1997, ele anunciou a criação do Ministério da Defesa. Foi uma manobra política para favorecer a candidatura do Brasil a um assento no Conselho de Segurança da ONU, já que seria difícil explicar ao mundo como um país com vaga neste Conselho aspira decidir sobre questões 
de segurança internacional tendo quatro ministros militares respondendo pela defesa. Afora isto, FHC também quis acabar com a figura de ministros militares por ter um projeto de implantação do parlamentarismo. Ficaria muito estranho se, numa queda de gabinete, todos os ministros caíssem com exceção dos militares (ZAVERUCHA, 2003, p. 406).

Partindo dessa última perspectiva, percebe-se que o MD nasceu com falhas genéticas sérias. Criado para subjugar os militares ao jogo político democrático, ou seja, controle efetivo civil sobre os militares, o MD teve, na verdade, fins instrumentais. O próprio relator do projeto de criação do dito ministério, Benito Gama, afirmou que o novo ministro seria uma espécie de "rainha da Inglaterra". Além da fragilidade instrumental do ministro da defesa este também passaria por fragilização institucional, pois os comandantes militares do Exército, da Marinha e da Aeronáutica só deixariam de ser politicamente ministros de Estado, não perdendo o seu status jurídico (ZAVERUCHA, 2003).

Os comandantes militares são membros do Conselho de Defesa Nacional. O ministro da Defesa tem de levá-los a cada reunião desse conselho. Os comandantes militares são aqueles que de fato detêm o poder, o ministro da defesa, civil, é um mero despachante das Forças Armadas perante o Presidente da República e o Congresso ${ }^{32}$. Os militares também são responsáveis, juntamente com o ministro da Defesa, pela indicação de oficiais-generais ao presidente da República (ZAVERUCHA, 2003).

32 A ideia de que a força militar tem de estar sob controle civil não é aceita pelos generais brasileiros. A demissão do diplomata José Viegas, do MD, substituído pelo vice-presidente José Alencar, mostra, de forma bastante clara, que os militares brasileiros ainda são incivilizados, ou seja, não aceitam o fato de que, em democracia, o poder emana dos civis, e a eles devem se sujeitar. A nota do Comando do Exército - que justificava à imprensa a morte do jornalista Vladimir Herzog nos porões da ditadura militar, em 1975 - fora divulgada à imprensa a revelia do ministro. Isso o deixou profundamente irritado. Teve a intenção de demitir o comandante do Exército, General Francisco de Albuquerque, mas teve de se contentar com uma retratação pública do General.

Na verdade, tal indisposição retirou Viegas do "comando" do MD e, como afirmou o Cientista Político da Universidade de Brasília (UnB), David Fleischer, "o problema é que nenhum ministro da Defesa até hoje teve autonomia no cargo. Nenhum deles teve poder para demitir os comandantes militares. Ainda não temos tradição na caserna de subordinação aos civis" (CABRAL, 2004). 
Desde 1985 os Presidentes da República acataram integralmente os nomes propostos pela cúpula militar para promoção.

No processo de indicação do primeiro ministro da defesa, ficou claro como a interferência verde oliva é cabal. FHC quis indicar um diplomata, Ronaldo Sardemberg, para o MD. Mas, como o Itamaraty tem uma rivalidade histórica com as Forças Armadas, o Presidente cedeu às pressões castrenses e escolheu o ex-líder do governo no Senado, Senador Élcio Álvares, que tinha sido derrotado nas eleições do seu estado, o Espírito Santo. Álvares assumiu na qualidade de ministro extraordinário da defesa. Interessante notar que, em seis meses, o Brasil conviveu com cinco ministérios na área da defesa: o MD, a Marinha, o Exército, a Aeronáutica e o EMFA. Álvares ficou numa situação incômoda, pois despachava numa salinha no quarto andar do prédio do EMFA, sendo depois transferido para uma outra sala, também de pequenas dimensões. O ex-senador só veio ocupar o gabinete do ministro-chefe do Estado Maior das Forças Armadas quando foi publicada no Diário Oficial a sua nomeação como ministro efetivo da Defesa. Quando assinava documento oficial, tinha de pedir a assinatura de seus subordinados, i.e., os comandantes militares.

Seus sucessores permaneceram como sendo figuras "ilustrativas". Qualquer pressão ou insatisfação militar os civis terminam por ceder. Depois da saída indecorosa de Álvares - acusado de envolvimento com o narcotráfico $^{33}$-, que gerou ato de indisciplina militar por parte do Brigadeiro Brauer, forçando-o a declarar publicamente seu repúdio para com o ministro (MARTINS, 1999).

33 Solange Antunes Resende, assessora e amiga de Álvares, tinha uma sociedade num escritório de advocacia com seu irmão e o então ministro da defesa. A revista Istoé noticiou que Resende juntamente com seus sócios, o irmão Dório Antunes e o ministro, teriam defendido clientes envolvidos com o narcotráfico (MEIRELES, 1999). Foi aberta uma CPI (Comissão Parlamentar de Inquérito) onde foi quebrado o sigilo bancário, fiscal e telefônico de Resende, do seu irmão e do ministro Élcio Álvares. Tal situação revoltou os militares que de ponto assumiram uma posição totalmente autônoma quanto ao fato, mostrando que não iriam assumir uma posição em favor do suposto "superior", pois nunca tinham o considerado dessa forma (MARTINS, 1999). 
Assumiu Geraldo Quintão, que até então era o Advogado Geral da União. Quintão começou seus trabalhos no MD anunciando ações que agradaram em cheio os militares: estudo para aumento de soldos; incremento de verbas para a modernização das três forças, e defesa de um sistema previdenciário diferenciado do civil (AZEREDO, 2000).

Tais promessas não foram cumpridas, gerando insatisfação entre os militares. Para complicar ainda mais a situação dos civis, FHC, resolveu demitir o comandante do Exército, general Gleuber Vieira, que tinha feito uma declaração criticando a falta de verbas. A crise se instalou, os castrenses se reuniram em Brasília para ato de desagravo, diga-se, sem a presença do ministro da defesa. FHC cedeu à pressão verde-oliva e voltou atrás na demissão do comandante do Exército, o general Gleuber Vieira. Os militares ainda pressionaram para que fosse editado uma Medida Provisória concedendo reajuste salarial, no que foram prontamente atendidos. Quintão permaneceu no cargo numa posição discreta, procurando não criar atritos com os militares.

Diferentemente de FHC, Lula conseguiu colocar no MD um diplomata, José Viegas. Apesar da aprovação do nome do diplomata para a cadeira do MD pelos comandos das Forças Armadas, isso não quis dizer que Viegas não teria o mesmo papel de seus antecessores, ou seja, ser uma figura ilustrativa, uma "rainha da Inglaterra". Mas, Viegas não levou a sério às regras do jogo no MD. Tomou medidas que desagradaram as três forças, sobretudo o comandante do Exército, General Francisco de Albuquerque.

Viegas criticou a falta de empenho do Exército, ao contrário das outras forças, na busca de corpos de desaparecidos políticos nos conflitos da Guerrilha do Araguaia, comportou-se como membro do governo entrando em choque com os quartéis ao aceitar a decisão da área econômica em não dar aumento salarial aos militares, solicitando, também, que os militares não fizessem declarações públicas em favor de aumentos salariais. 
A "quebra-de-braço" entre o ministro e o comando do Exército se tornou bastante clara no caso da nota que o general Francisco de Albuquerque direcionou à imprensa sobre o caso das supostas fotos de Vladimir Herzog sendo torturado nos porões da ditadura, publicadas no Correio Brasiliense ${ }^{34}$. Tal nota foi considerada ofensiva pelo presidente Lula. Ela afirmava que o Exército não tinha mudado suas convicções sobre o acontecido no período da ditadura.

O Exército falou em nome do MD, sem consentimento das outras forças e, muito menos, do ministro da defesa, Viegas. Este exigiu retratação do comandante do Exército general Francisco de Albuquerque, no qual redigiu uma nova nota que, substancialmente, não mudava em quase nada a essência da nota anterior. No final das querelas, Viegas saiu do comando do MD.

Assumiu a pasta da Defesa o vice-presidente, José Alencar. Este não podia ser demitido, pois, num eventual impedimento do presidente Lula, ele seria o comandante-em-chefe das Forças Armadas. José Alencar entregou o cargo em outubro de 2006 para disputar as eleições. O ministro atual é Waldir Pires. Este está envolvido num dos maiores problemas enfrentados pelo MD na Nova República, a questão dos controladores de vôos. Fica clara a fragilidade do ministro que não consegue dirimir este sério problema e, pior, não esclarece aos cidadãos quais são os verdadeiros problemas que estão infringindo o espaço aéreo brasileiro, porque, simplesmente, não está a par do que acontece nos CINDACTAs (Centros Integrados de Defesa Aérea e Controle do Tráfego Aéreo). Estes estão sob (des)controle da Aeronáutica. O pacto da transição permanece, os militares aceitam uma semidemocracia em troca da manutenção de enclaves autoritários dentro do aparato do Estado ${ }^{35}$.

34 Ficou comprovado que aquelas fotos não eram de Vladimir Herzog.

35 São domínios reservados implicando em clara transgressão ao critério da efetivação de governos eleitos que de fato governam sem sofrer nenhum tipo de impedimento nos bastidores. As relações civil-militares no Brasil ainda não conseguiram superar este aspecto. 
As três forças são independentes do $M D$, ou seja, do controle civil. O controle institucional do orçamento das Forças Armadas pelo Congresso Nacional é meramente contábil. Sem maiores esclarecimentos das estratégias previamente definidas. O MD não tem a menor intenção de mudar esta realidade:

Não basta um representante da vontade presidencial exercendo o cargo de ministro para configurar a direção política, mas a presença decisiva de civis no cerne da formulação e implantação dos rumos da defesa e das questões militares (OLIVEIRA; SOARES, 2000).

Partindo do papel institucional do MD para a questão da coordenação do setor de defesa da nação, têm-se observado que o controle civil se mostra frágil. Com os defeitos genéticos do $\mathrm{MD}$ relatados aqui, a coordenação do setor de defesa, ou segurança pública estatal, se mostra bastante militarizada.

Stepan (1988) coloca que, para que a prerrogativa militar - coordenação do setor de defesa - tenha baixa intensidade de jure e de facto, a coordenação desse setor tem de ser realizada por uma autoridade no quadro ministerial (em geral, um civil indicado pelo Executivo federal) que controle uma equipe, em grande parte constituída por funcionários civis nomeados. Para Stepan (1988), a prerrogativa militar terá alta intensidade se tal coordenação for realizada, de jure e de facto, pelos comandos das três forças armadas militares, atuando de modo separado, sob a fiscalização muito frágil do EMFA e contando com frágil participação do Executivo federal (STEPAN, 1988, p. 526).

Sabe-se que o setor de defesa, ou Defesa Nacional, é atividade do Ministério da Defesa em países efetivamente democráticos. Que o MD é responsável pelo planejamento e execução dos assuntos voltados para a Defesa da Nação, onde as Forças Armadas tem papel de destaque nessa garantia. Cabe aos civis executar as atividades de coordenação e de ela- 
boração dos planejamentos de defesa, bem como administrar o orçamento de defesa com total independência. Pelo que se viu o que ocorre é justamente o predomínio das Forças Armadas em todos estes requisitos. Exemplo típico de hibridismo institucional, o MD apresenta-se como uma instituição que fortalece o conceito de semidemocracia. Numa fachada democrática encontramos uma série de entraves autoritários.

O MD aparece, à primeira vista, como um grande avanço para a consolidação da democracia no Brasil, mas, na verdade, esconde nos bastidores a verdadeira ação em seu bojo, ou seja, o domínio dos castrenses como força política no planejamento, gestão e execução das atividades de Defesa. Tem-se um domínio de jure de um ministro fraco, mas de facto o que se verifica é a autonomia dos comandos militares (Exército, Aeronáutica e Marinha) na condução do Ministério da Defesa.

Outro exemplo de ingerência militar em assuntos de esfera civil encontra-se nas agências de inteligência brasileira. Ali os militares aparecem novamente como veto players (TSEBELIS, 1995), mantendo o mesmo desenho institucional dessas instituições hoje conforme as do período de exceção.

Ponto forte que mostra destacada influência dos militares em nossa frágil democracia, é o que diz respeito ao controle das Agências de Inteligência. No Brasil há fraca fiscalização parlamentar neste quesito. Isso ocorre fazendo com que princípios básicos da liberdade individual sejam infringidos quase a todo instante por questão da ingerência militar em tais instituições e da manutenção de uma lógica do regime militar da busca incessante do inimigo interno, lógica esta que segue a Doutrina de Segurança Nacional do período de exceção brasileiro. Modus operandi do ancien regime continuam a fazer parte do setor de inteligência interna (que deveria ser dominada por civis) e externa. As atividades de inteligência civis e militares se misturam, onde os atores políticos militares se destacam por influírem e agirem em assuntos de inteligência interna (ZAVERUCHA, 2000). 
O Centro de Informação do Exército $(\mathrm{CIE})^{36}$ mantém, em regime dito democrático, prerrogativas relevantes quanto ao seu papel interno, como demonstra o artigo 5o da Portaria no 323, de 31 de março de 1981, onde tem destacado o seu papel:

orientar, coordenar e desenvolver atividades de informações internas e de segurança interna, bem como contra-informações do sistema de informações do Exército. Assessorar o ministro nos assuntos de informações internas e nas de contra-informações.

O chefe desse órgão, em 1997, o General Cláudio Figueiredo, afirmou que o CIE não mais participava das operações, apenas assessorava. Com isso, foi criado o EsIMEx (Escola de Inteligência Militar do Exército) para o exercício desse assessoramento (ZAVERUCHA, 2000, p. 40). Mas, apesar desse caráter de assessoramento que o General Figueiredo afirma ter o $\mathrm{CIE}$, tal instituição exerce presença ativa na coleta de informações e contrainformações para assuntos de segurança internos, mantém-se, assim, com sua proposta inicial.

Os serviços de inteligência das Polícias Militares ( $\left.\mathrm{P}-2^{37}\right)$ continuam agregados ao sistema de informações do Exército, como no período da ditadura militar ${ }^{38}$. As PMs são obrigadas, por lei, a passar as informações coletadas através do chamado "canal técnico" ao comando do Exército. As informações perpassam sobre o governador do Estado. Para completar, não há qualquer controle das Assembléias Legislativas estaduais sobre os serviços de inteligência das PMs. Também o controle parlamentar em assuntos orçamentários é bastante limitado, para não dizer inexistente. A formatação institucional das PMs, como se encontra hoje, é um claro exemplo de hibridismo institucional e tem reflexo direto no setor de inteligência dos militares estaduais. Como servem a "dois patrões", o comando

36 Criado em 1967, ápice do regime autoritário.

37 Serviços de Inteligência das Polícias Militares Estaduais.

38 Conforme Decreto no 88.777, de 30 de setembro de 1983. 
do Exército de um lado e o governo do Estado de outro, a accountability horizontal (O’DONNELL, 1998) fica comprometida, a obrigatoriedade de passagem das informações das P-2 para o comando do Exército demonstra uma característica privilegiada que as Forças Armadas tem em relação ao governador.

A ABIN (Agência Brasileira de Inteligência) ${ }^{39}$ é outra instituição com características militares. Criada no período do governo de FHC, esta instituição ficou atrelada ao Gabinete de Segurança Institucional (GSI) ${ }^{40}$. Este órgão é permeado por uma estrutura militarizada, onde substituiu a extinta Casa Militar. No governo FHC quem comandava a ABIN era o General Cardoso, que foi o militar com maiores atribuições civis da História republicana do Brasil (ZAVERUCHA, 2003). O resultado disso foi uma formatação institucional muito parecida com a do antigo SNI (Serviço Nacional de Informações), do antigo regime autoritário.

A formatação institucional da ABIN fragiliza a democracia brasileira. Nesta instituição existe uma série de fatores que podem ser colocados como sendo anacrônicos para o desenvolvimento de um serviço de inteligência efetivo e responsivo em nosso país. Como a inteligência é um bem público arduamente disputado entre os grupos que almejam controlar o estado (ZAVERUCHA, 2006), é fundamental que este esteja sob controle civil. Mas, em nossa análise factual, o que se vê é um forte esquema montado sob orientação militar.

A lei que criou a ABIN é nebulosa, diz que cabe a esta instituição "fornecer subsídios ao presidente da República nos assuntos de interesse nacional", não vindo a definir o que seja "interesse nacional". Isso faz

39 No final do primeiro governo de FHC foi sancionada a Lei n. 9.883, que instituiu o Sistema Brasileiro de Inteligência (Sisbin). Neste mesmo processo legal foi criada a Agência Brasileira de Inteligência (ABIN) como órgão central do Sisbin (ZAVERUCHA, 2005, p. 159).

40 FHC, por meio de Medida Provisória, no 1994-4, de 13 de janeiro de 2000, tirou a ABIN da subordinação da Presidência da República e a colocou sob controle do GSI. 
com que cada presidente da República venha a definir o que seja. A vacância nessa definição é muito séria numa perspectiva de Estado, sobretudo quando este Estado afirma estar baseado em um regime democrático. Outro ponto é que os militares podem, também, decidir o que é de "interesse nacional", pois, como garantes da lei e da ordem, sua filosofia, estrutura, ideologia e etc. influenciam diretamente no que eles acreditam ser seu de direito: "a defesa da pátria e da honra nacionais". O Estado acima de tudo, inclusive da própria democracia.

A ABIN deveria ficar, de forma direta, subordinada ao presidente da República, no entanto, logo após a sua criação, FHC, via medida provisória, deixou-a subordinada ao general ministro-chefe do GSI (Gabinete de Segurança Institucional), cargo de natureza militar. O general é quem efetivamente manda, filtrando quais informações devem chegar às mãos do presidente (ZAVERUCHA, 2006). Esta instituição, como está formatada, consolida a Doutrina de Segurança Nacional nos moldes do regime anterior a 1985, mantendo um entulho autoritário, fazendo com que direitos fundamentais fiquem à mercê de interesses castrenses. O que vale é a vigilância do possível inimigo do sistema.

No governo Lula as coisas não mudaram, apesar de advir de um partido de esquerda. A indicação do delegado Mauro Marcelo da Lima e Silva para dirigir a $A B I N$, em substituição à Marisa Almeida Del'Isola e Diniz, gerou grande insatisfação no meio das FFAA. A escolha do nome de Lima e Silva foi indicação do Presidente. O ministro-chefe do Gabinete de Segurança Institucional da Presidência da República, General Jorge Armando Félix, criticou a indicação e a desconsideração do Presidente, pois o mesmo não levou em consideração as insatisfações castrenses (ROMERO; CALDEIRA, 2004).

Os militares que criticaram reservadamente a indicação de Lima e Silva para a direção da $\mathrm{ABIN}$, alegavam que o delegado tinha uma forte aproximação com o FBI - Polícia Federal dos EUA, onde o delegado par- 
ticipou, a convite da instituição, de um curso de especialização. Lima e Silva disse que sua ligação com o FBI deveria ser vista como uma conquista individual da qual ele se orgulhava e que as críticas existiriam mesmo se ele tivesse feito qualquer curso, em qualquer parte do globo. Na verdade, a crítica levantada pelos militares visava destacar a sua insatisfação em ter arranhada uma prerrogativa, que é um legado do regime autoritário, que eles acreditam ser sua de direito. ${ }^{41}$

Tal resistência estava no fato de Lima e Silva ser o primeiro policial civil a comandar o departamento de inteligência do governo brasileiro, aproximando mais o órgão do Presidente, já que existe uma relação tensa da presença militar no combate à violência urbana e na divisão de tarefas na repressão ao narcotráfico nas fronteiras nacionais. É importante colocar que diante da simples insinuação dos civis tentarem puxar pra si o domínio dessa instituição, que é considerado um domínio reservado por parte dos castrenses, ocasiona mal estar entre os militares que não querem perder suas prerrogativas.

Em julho de 2005, depois de forte pressão política por parte do General Jorge Armando Félix (que comanda o GSI atualmente), o delegado Mauro Marcelo Lima e Silva foi demitido, tendo sido nomeado para seu lugar Márcio Paulo Buzanelli, veterano do antigo SNI (Serviço Nacional de Informações). A vitória política do General Félix significa, também, a perpetuação do SNI, órgão de inteligência do período ditatorial militar na década de 1970.

$\mathrm{O}$ aspecto da fragilidade democrática da ABIN se apresenta na formalidade e na informalidade. A Lei 9.883, que rege esta instituição, afirma em seus artigos pontos que levam a uma ampla interpretação. Em seu artigo 10.

41 A ABIN se apresenta como uma prerrogativa militar de alta intensidade (STEPAN, 1988), pois sua estrutura se mantém bastante militarizada e quando há qualquer tentativa de subjugá-la a controle civil há forte resistência do alto oficialato militar para não ser fragilizada tal prerrogativa. A indicação de um policial civil sinalizava a possibilidade de desmilitarização da agência, o pouco período de comando de Lima e Silva demonstra que houve recuo civil numa esfera de "natureza" militar. 
fica instituído o Sistema Brasileiro de Inteligência, que integra as ações de planejamento e execução das atividades de inteligência do País, com a finalidade de fornecer subsídios ao presidente da República nos assuntos de interesse nacional.

Como se observa neste artigo, há uma prerrogativa nas mãos do presidente. Assuntos relacionados à inteligência colocam o Poder Executivo a frente dos outros poderes da República, o presidente tem liberdade de utilizar os serviços da ABIN para fins políticos, vindo a ferir direitos políticos e civis, demonstrando claro exemplo de autoritarismo civil, corroborando ainda mais para o poder desproporcional do presidencialismo brasileiro ${ }^{42}$.

O Congresso Nacional tem na Comissão Mista de Controle das Atividades de Inteligência (Ccai) o órgão responsável pela fiscalização dos assuntos de inteligência. No entanto, este órgão não tem competência quando o assunto é a inteligência das FFAA e da Polícia Federal (que faz parte do Ministério da Justiça). Dessa forma, não penetra nas instâncias mais importantes do setor de inteligência. É cada vez mais independente a ação de investigação e de informação da Polícia Federal. Sem fiscalização de natureza jurídica ou legislativa pode-se ter no Brasil uma estrutura de estado policial onde a informação fica à mercê de interesses particularistas e não da garantia do Estado de Direito democrático, vindo a ferir direitos fundamentais.

As atividades de inteligência no Brasil, segundo artigo da Lei 9.883, são de natureza civil e militar. Como já destacado linhas acima, isso vem misturar a sua competência, pois as $\mathrm{P}-2 \mathrm{~s}$ passam a ser vinculadas à $\mathrm{ABIN}$. Sabe-se, de antemão, que as atividades de inteligências das PMs são de inteira responsabilidade do Exército. Tal arranjo institucional, bastante complexo e esdrúxulo, abriu espaço para a atuação desproporcional dos mili-

42 Há fraco controle parlamentar nos assuntos de Inteligência. De acordo com o art. $6 \underline{0}$ da Lei 9.883, o Poder Legislativo "ficou responsável pelo controle e fiscalização externos da atividade de inteligência. Contudo o $\S 1$ o deste mesmo artigo contribuiria para tornar este controle algo muito mais teórico que factual. Em vez de ser criada uma comissão específica e fixa para exercer este controle, optou-se por um órgão composto pelos líderes da maioria e da minoria na Câmara de Deputados e no Senado Federal, assim como os presidentes das Comissões de Relações Exteriores e Defesa Nacional da Câmara dos Deputados e do Senado Federal" (ZAVERUCHA, 2005, p. 162). 
tares em um bem público que é a inteligência. A própria formatação das PMs (militares estaduais) é confusa, pois esta instituição tem vínculo com o Poder Executivo estadual e o comando do Exército. Tal estrutura é ineficiente e contribui para o fortalecimento do autoritarismo e do clientelismo.

A ABIN mantém em seu bojo uma racionalidade de segurança nacional em defesa do Estado contra o inimigo interno, não existe atribuição da instituição à esfera civil na defesa da ordem pública. Existe uma lista imensurável de denúncias de espionagem política por parte da $\mathrm{ABIN}$. A racionalidade de perseguição política se mantém como na época do SNI da ditadura. Arapongagem e investigações com fins políticos estão na ordem do dia.

Alguns exemplos podem ser colocados para reforçar a discussão. Os direitos individuais são ameaçados sem que haja uma medida severa de punição aos atos de ilicitude da ABIN. Espionagem de presidentes e expresidentes, como foi o caso de Itamar Franco, é um exemplo cabal de desmando. Itamar fora investigado desde março de 1998, quando tentou sair candidato pelo PMDB a presidência da República. A ABIN produziu vários relatórios sobre o investigado, inclusive de cunho financeiro, onde invadiu o sigilo bancário e fiscal do ex-presidente.

O jornalista Andrei Meireles, da revista IstoÉ, também foi investigado. Ele apurava o eventual envolvimento do ex-secretário-geral do Palácio do Planalto, Eduardo Jorge Caldas Pereira, no escândalo do desvio de verbas da obra do Tribunal Regional do Trabalho, em São Paulo. Outra revista de grande veiculação nacional, Veja, revelou a ficha ideológica de Andrei Meireles. Esta teria sido revelada por arapongas da $\mathrm{ABIN}$, afirmando que o mesmo tinha pertencido ao Partido Comunista Brasileiro, que foi do sindicato de jornalistas e participou de um encontro sindical em Cuba. Clara perseguição política ao inimigo interno da época da ditadura militar, i.e., a 
Lei de Segurança Nacional tal como idealizada pela ESG (Escola Superior de Guerra) e sua Doutrina de Segurança Nacional ${ }^{43}$ (ALVES, 1984).

O Sistema Brasileiro de Inteligência tem como fundamentos a defesa do Estado Democrático de direito e a dignidade da pessoa humana, devendo ainda cumprir e preservar os direitos e garantias individuais e demais dispositivos da Constituição Federal. Há um choque entre os dispositivos constitucionais e os códigos formais e informais das instituições de inteligência brasileiras. O principal órgão de inteligência do país serve para fins políticos e, dessa forma, passa por cima do Estado de Direito democrático, pois é um órgão do Estado que deturpa a lei. Sua formatação híbrida é responsável por tal funcionamento contraditório.

O ranço autoritário ainda se mostra bem forte dentro da ABIN. O maior número de assentos dentro dessa instituição é de militares. Dessa forma, as informações cedidas pelas secretarias de Segurança Pública estatais são direcionadas para as mãos dos militares federais, principalmente quando trata de distúrbios sociais. A agência também pode agir de forma a obstaculizar avanços quanto aos direitos humanos no Brasil, sobretudo a respeito de informações do período autoritário. Existe uma clara "quebra de braço" entre civis e militares dentro da ABIN, onde o GSI aparece, até o momento, na frente da disputa pelo controle dessa agência de inteligência ${ }^{44}$.

43 "A Lei de Segurança Nacional (LSN) é a formalização jurídica dos princípios da Doutrina de Segurança Nacional. Doutrina esta que se desenvolveu no âmbito da Guerra Fria e do Regime Militar (1964-1985). A última versão da LSN é de 14 de dezembro de 1983 (Lei n. 7.170), aprovada nos estertores do governo do general Figueiredo. A ótica desta doutrina era dirigida para o combate do inimigo interno" (ZAVERUCHA, 2005, p. 183).

$44 \mathrm{O}$ processo de militarização desta instituição de inteligência fica bem demonstrado quando são observados os símbolos que a demarcam. O atual diretor, de escolha pessoal do general titular do GSI, "instituiu o carcará ('pega, mata e come') como ave-símbolo da agência. Na nova logomarca, o carcará aparece sobrevoando o planeta terra, no qual se lê o dístico 'Em Defesa do Brasil" , o atual diretor-geral também mudou a terminologia dos cargos, agora são comandante, comandante adjunto, (sub)oficiais de inteligência, e (sub)comissários, tais insígnias guardam paralelo às patentes de coronel, tenente-coronel, major, capitão etc. O hino da instituição lembra o compromisso com a honra, a pátria e o Estado (ZAVERUCHA, 2006). 


\section{Conclusão}

Numa concepção submínima da democracia (SCHUMPETER, 1984; PRZEWORSKI et al, 2001), eleições livres, limpas, competitivas e periódicas podem instituir como sendo democrático qualquer país, em qualquer parte do globo. Já numa definição minimalista da democracia, aqui em enfoque, esse critério é importante, mas não é suficiente para a afirmação que determinado país é, efetivamente, democrático. Nela podem existir países que nem são democracias, nem regimes efetivamente autoritários. Numa análise que utiliza a definição minimalista da democracia colocada neste trabalho, alguns países podem se enquadrar numa zona cinzenta, híbrida, sendo tais países classificados como semidemocráticos ou semiautoritários (MAINWARING et al, 2001; OTTAWAY, 2003).

Esse hibridismo institucional fica bastante claro no caso das instituições coercitivas do Brasil. Esse fenômeno leva à falta de garantias individuais que são imprescindíveis para a democracia contemporânea, baseada no seu componente liberal. O Devido Processo Legal no Brasil dista em sua conotação liberal ao modelo anglo-americano. $\mathrm{O}$ due process of law da jurisprudência norte-americana leva em consideração mais o aspecto individual do que as prerrogativas do Estado e do ente lesado pela infração. Há uma preocupação original com o direito de cidadania, na garantia individual de não sofrer nenhum tipo de impedimento da liberdade sem que haja o processo e suas idiossincrasias, onde a pretensão de defesa supera a culpabilidade do ente acusado. No Brasil ocorre o inverso, a culpabilidade do ente acusado supera a sua pretensão de defesa.

Com a militarização cada vez mais acentuada da segurança pública, fica visível que o viés estatal perpassa o caráter liberal do individualismo. O Estado aparece como sendo o ator principal e o cidadão como mero ator passivo. As prerrogativas militares não foram dirimidas e, como foi visto, em plena dita "democracia" (política) temos mantidas tais prerroga- 
tivas dando aos militares grande poder de barganha política em assuntos que deveriam estar nas mãos dos civis eleitos pelo povo.

Essa falta de cidadania não coaduna com a democracia. Numa visão submínima da democracia, onde a questão eleitoral é a única que importa, estar-se-á o indivíduo colocado em segundo plano, os atributos liberais são colocados como elementos que devem ser negligenciados, pelo "bem da ciência", esquecendo que a falta dos mesmos pode levar o regime político a retroceder para um regime propriamente autoritário, como ocorreu recentemente na Tailândia.

Sem garantias mínimas para os indivíduos, colocadas aqui na presença do aparelho de Estado, na figura do Devido Processo Penal, que são os seus direitos de não sofrerem arbitrariedades nem do Estado e nem dos outros indivíduos, com regras claras e coniventes com a lei máxima, a constituição, não pode se dizer que há democracia consolidada.

Sem um efetivo controle da coisa pública por parte daqueles que foram eleitos pelo povo no processo de escolha de governantes, fica também bastante difícil de afirmar que temos democracia sólida em nossas plagas. E isso fica bastante claro quando é observado o modelo de segurança pública aplicada no Estado brasileiro.

Ofuscado pelos militares, que têm atribuições bastante elevadas em nosso país, os civis não conseguem efetivar um processo de segurança pública democrático. O que prevalece é uma estrutura militarizada, herança do período autoritário, que não avança para uma outra estrutura comandada de forma eficiente por civis capacitados e direcionados para uma realidade de Estado de Direito Democrático.

No atual quadro brasileiro, configurado por um Poder Judiciário que não garante efetivamente os direitos de cidadania e com uma estrutura de descontrole civil sobre os militares, representado aqui pelo processo de militarização da segurança pública, o que temos contemplado apenas 
é uma forma submínima da democracia, i.e., com eleições "livres" e limpas, competitivas, periódicas, pluripartidárias e com alternância no poder, com uma grande gama de civis participando desse processo, mas que não consolida, e parece nem pretender consolidar, a democracia. Dessa forma, definindo-a como sendo uma semidemocracia, ou seja, um sistema de hibridismo institucional que tem características de regime democrático e, também, de regime autoritário.

\section{The Brazilian Semi-democracy: authoritarianism or democracy?}

\section{Abstract}

Democracy has not yet been consolidated in Brazil. It is what Mainwaring et al (2001) called semi-democracy, i.e., a political system characterized by its institutional hybridism, presenting advanced features of (political) democracy, as well as some visibly authoritarian characteristics. This article intends to discuss the Brazilian semi-democracy analyzing the state's institutions of coercive power. The justice system and the public safety are examined in a context where the political and the historical explanation complement each other. Starting from a minimalist conception of democracy, the article analyzes some coercive institutions to contrast the theory with the formal and informal reality of these institutions.

Keywords: Semi-democracy. Due process (criminal). Due process of law. Police and civil-military relations.

\section{Referências}

ALVAREZ, Mike; et al. Classifying Political Regimes. Studies Comparative International Development, vol. 31, pp. 3-36), 1996.

ALVES, Maria Helena Moreira. Estado e oposição no Brasil (1964-1984). Petrópolis: Vozes, 1984. 
AZEREDO, Zenaide. Ministro assume prometendo aumento. Jornal de Brasília, 25 de janeiro, 2000.

BATISTA, Weber Martins; FUX, Luiz. Juizados Especiais Cíveis e Criminais e Suspensão Condicional do Processo Penal. Rio de Janeiro: Forense, 1998.

BLAT, José Carlos; SARAIVA, Sérgio. O caso da Favela Naval. São Paulo: Contexto, 2000.

BOBBIO, Norberto. A era dos direitos. Rio de Janeiro: Campus, 1992.

BRESSER PEREIRA, Luiz Carlos. Da Administração Pública Burocrática à Gerencial. In: Reforma do Estado e Administração Gerencial. Rio de Janeiro: FGV, 1998.

. Argumentação e debate. Folha de S. Paulo, 12 de novembro, 2002.

. O medo venceu a esperança. Folha de S. Paulo, 9 de novembro, 2003.

CARVALHO, José Murilo de. Cidadania no Brasil: o longo caminho. 3 ed. Rio de Janeiro: Civilização Brasileira, 2002.

CERQUEIRA, Carlos M. Nazareth. Questões preliminares para a discussão de uma proposta de diretrizes constitucionais sobre a Segurança Pública. Revista Brasileira de Ciências Criminais, Ano 6, n. 22, p. 139-182, 1998.

CONSTITUIÇÃO DO BRASIL, Recife: Companhia Editora de Pernambuco, 1989.

CORWIN, Edwuard S. A constituição norte americana e seu significado atual. Tradução de Leda Boechat Rodrigues. Rio de Janeiro: Zahar, 1986.

DAHL, Robert. Poliarquia: participação e oposição. São Paulo: Edusp, 1969.

ECONOMIST INTELLIGENCE UNIT. The Economist Intelligence Unit's index of democracy, The World in 2007, 2006.

FEREJOHN, John; PASQUINO, Pasquale. A Teoria da Escolha Racional na Ciência Política: Conceitos de Racionalidade em Teoria Política. Revista Brasileira de Ciências Sociais, v. 16, n. 45, 2001.

FERREIRA, Marcos Aurélio G. O Devido Processo Penal - Um estudo comparativo. Lumiere, 2004.

GASPARI, Elio. A Ditadura escancarada. São Paulo: Cia das Letras, 2002.

HABERMAS, Jurgen. Direito e Democracia: entre facticidade e Validade, Rio de Janeiro: Tempo Brasileiro, Cap. VII, Política Deliberativa: Um Conceito Procedimental de Democracia, p. 9-55 e Cap. VIII, O Papel da Sociedade Civil e a Nova Esfera Pública, p. 57-121, 1997.

HELD, David. Modelos de Democracia. Belo Horizonte: Paidéia, p. 132-199, 1987. 
KANT DE LIMA, Roberto. A polícia da cidade do Rio de Janeiro. Seus dilemas e paradoxos. 2a Edição Revista. Rio de Janeiro: Editora Forense, 1995.

. Polícia, Justiça e Sociedade no Brasil: uma abordagem comparativa dos


e Política, n. 13, Curitiba, p. 23-38, 1999.

KARL, Terry Lynn. Imposing Consent? Electoralism vs. Democratization. in El Salvador. DRAKE, P. W.; SILVA, E. (eds.), Elections and Democratization in Latin América, 1980-1985. La Jolla, Center for Iberian and Latin American Studies, University of Califórnia at San Diego, 1986.

JORNAL DO COMMERCIO. Lula, um presidente que fala demais. Caderno Política, Recife, 1을 je julho, p.12, 2007.

LOPES, Roberto. Sem Defesa. Folha de S. Paulo, 11 de maio, 2001.

MACEDO, Ana Paula. FH a militares: Brasil é um dos países mais democráticos do mundo. O Globo, 18 de dezembro, 2002.

MAINWARING, Scott et al. Classificando regimes políticos na América Latina, 1945-1999. Dados, v. 44, n 4. Rio de Janeiro, 2001.

MARIANO, Benedito. O exemplo da polícia canadense. Folha de S. Paulo, 25 de fevereiro, 1998.

MARTINS, Franklin. Crônica de uma crise militar anunciada. Jornal de Brasília, 19 de dezembro, 1999.

MASSON, Celso; AZEVEDO, Solange; FERNANDES, Nelito. Um marco histórico no combate à violência. Revista Época. São Paulo: Editora Globo. Edição de capa, 2 de julho, 2007.

MEIRELES, A. Defesa aberta. Istoé, São Paulo, 6 de outubro, 1999.

MELO FILHO, Hugo Cavalcanti. A independência judicial como fenômeno positivo para a Democracia. Uma Análise da Interferência do Poder Político no recrutamento dos Juízes Brasileiros. 203 p. Dissertação de Mestrado apresentada ao Programa de Pós-Graduação em Ciência Política da UFPE. 2002. 203 p.

MIGUEL, Luis Felipe. A Democracia domesticada: bases antidemocráticas do pensamento democrático contemporâneo. Dados, Rio de Janeiro, v. 45, n. 3, p. 483 a 511, 2002.

MIRABETE, Juliu Fabrini. Código de Processo Penal interpretado. São Paulo: Atlas, 1997.

. Processo Penal. 16 a edição atualizada. São Paulo: Atlas, 2004.

MORAES, Bismael B. A polícia à luz do Direito. São Paulo: Ed. Revista dos Tribunais, 1991. 
NEUBAUER, David W. America's Courts \& Criminal Justice System. Califórnia: Brooks/Cole Publishing Company, 1988.

NÓBREGA JR, José Maria P. Teoria democrática contemporânea: as concepções minimalistas e seus críticos contemporâneos. Política Hoje. Recife: Ed. Livro Rápido, n. 14, p. 155-176, 2004.

. As instituições coercitivas e a semidemocracia brasileira. P.150. Dissertação de Mestrado apresentada ao Programa de Pós-Graduação em Ciência Política da UFPE, 2005. 150 p.

O’DONNELL, Guillermo. Teoria Democrática e Política Comparada, Dados, v. 42, n. 4, Rio de Janeiro, 1999.

. Poliarquia e a (In)efetividade da Lei na América Latina: uma conclusão parcial. In: Democracia, Violência e Injustiça. O não-Estado de Direito na América Latina. São Paulo: Paz e Terra, 2000.

. "Accountability horizontal e novas poliarquias". Lua Nova, n. 44, 1998.

. Teoria Democrática e Política Comparada. Dados, v. 42, n. 4, Rio de Janeiro, 1999.

OLIVEIRA, Luciano. Direito Processual e Direito Penal Oficial: relações insuspeitas. Trabalho apresentado ao VI Encontro da Associação Nacional de Pós-Graduação e Pesquisa em Ciências Sociais, ANPOCS, 1982.

OLIVEIRA, Eliézer Rizzo de; SOARES, Samuel Alves. Brasil, Forças Armadas, direção política e formato institucional. Democracia e Forças Armadas no Cone Sul. Orgs. Maria Celina D’Araújo e Celso Castro. Rio de Janeiro: FGV, 2000.

OLSON, Mancur. A Lógica da Ação Coletiva. Os benefícios públicos e uma teoria dos grupos sociais. São Paulo: Edusp. p. 17-72, 2002.

OTTAWAY, Marina. Democracy Challenged. The rise of Semi-authoritarianism. Washington, D.C.: Carnegie Endowment for International Peace, 2003.

PRADO, Antonio. A queda da desigualdade e da pobreza no Brasil. In: Visão do desenvolvimento. TORRES FILHO, Ernani Teixeira; PUGA, Fernando Pimentel; FERREIRA, Francisco Marcelo Rocha (Orgs.). Editado pelo BNDES, 2006.

PRZEWORSKI, Adam. Minimalist conception of Democracy: a defense. In: SCHAPIRO, Ian; HACKER-CORDÓN, Casiano. (Eds.), Democracy's value. Cambridge, p. 23-55, 1999.

et al. Democracy and development. Political Institutions and Well-Being in the World, 1950-1990. Cambridge University Press. Cambridge Studies in the Theory of Democracy, 2000. 
. Accountability social en América Latina y más allá. In: PERUZOTTI, Enrique; SMULOVITZ, Catalina (Eds.). Controlando la Política. Buenos Aires: Temas Grupo Editorial, 2001.

ROMERO, Cristiano; CALDEIRA, Ilton. Indicação de policial para dirigir a Abin desagrada Forças Armadas. In: Valor, 21 de novembro, 2004.

REIS, Bruno P. W. Ir para casa em paz: a economia das virtudes, e a apatia como direito. Trabalho preparado para apresentação em mesa sobre "Justiça, virtudes e o bem comum" junto ao GT "República e Cidadania", no XXVI Encontro Nacional da ANPOCS, em Caxambu, 24 de outubro, 2002.

SARNEY, José. Boa noite, Presidente. Folha de S. Paulo, 2004.

SARTORI, Giovanni. Parties and party systems: a framework for analysis. New York: Cambridge University Press, 1976.

SCHEINKMAN, José Alexandre. Cidades só crescem sem crime. Revista Época, Rio de Janeiro, Entrevista, p. 90, 2007.

SCHUMPETER, J. Capitalismo, Socialismo e Democracia. Rio de Janeiro: Zahar Editores, 295-376, 1984.

SHAPIRO, Ian. The State of Democratic Theory. Princenton: Princenton University Press, 2003.

SEN, Amartya. Desenvolvimento como Liberdade. São Paulo: Cia das Letras, 1999.

SKIDMORE, Thomas E. A lenta via brasileira para a democratização: 1974 - 1985. In: Democratizando o Brasil. Alfred Stepan (Org.). Rio de Janeiro: Paz e Terra, 1988, p. 27-81.

STEPAN, Alfred. As prerrogativas militares nos regimes pós-autoritários: Brasil, Argentina, Uruguai e Espanha. Democratizando o Brasil. Alfred Stepan (Org.). Rio de Janeiro: Paz e Terra, p. 521-562, 1988.

TAYLOR, Charles. A Política do Reconhecimento. In: Argumentos Filosóficos. São Paulo: Loyola, 2000.

TEIXEIRA MENDES, Regina Lúcia. Igualdade à brasileira: cidadania como instituto jurídico no Brasil. Revista de Ciências Criminais, n. 13, PUC/RS, Porto Alegre. Ed. Notadez, 2004.

TOCQUEVILLE, Aléxis de. A democracia na América. Tradução de Eduardo Brandão. São Paulo: Martins Fontes, 1998.

TORNAGHI, Hélio Bastos. Instituições de Processo Penal, v. 1, São Paulo: Saraiva, 1977. 
TSEBELIS, George. Processo decisório em sistemas políticos: veto players no presidencialismo, parlamentarismo, multicameralismo e pluripartidarismo. British Journal of Political Science, 1995.

VALENZUELA, J. Samuel. Democratic Consolidation in Post-Transitional Settings: Notion, Process and Facilitating Conditions. In: MAINWARING S.; O'DONNELL G.; VALENZUELA J. S. (Eds.). Issues in Democratic Consolidation: the new south american democracies in comparative perspective. Notre Dame, University of Notre Dame, p. 57-104, 1992.

VITA, A. Liberalismo igualitário e multiculturalismo. Sobre Brian Barry, Culture and Equality. Lua Nova, n. 55-56, São Paulo, 2002.

WEBER, Max. Economia e Sociedade, Cap. IX. Sociologia da Dominação, Seção 8 - A instituição estatal racional e os modernos partidos políticos e parlamentos (Sociologia do Estado), Brasília: Ed. UnB, p. 517-568, 1999.

ZAKARIA, Fareed. The Rise of Iliberal Democracy. Foreign Affairs, v. 76, n. 6, 1997.

. The Future of Freedom. Nova York: W.W. Norton \& Company, 2003.

ZAVERUCHA, Jorge. A constituição brasileira de 1988 e seu legado autoritário: formalizando a democracia, mas retirando sua essência. In: Democracia e Instituições Políticas Brasileiras no Final do Século XX. Org. Jorge Zaverucha. Recife: Ed. Bagaço, p. 113-147, 1998.

. Frágil Democracia. Collor, Itamar, FHC e os Militares (1990-1998). Rio de Janeiro: Civilização Brasileira, 2000.

. (Des)controle Civil sobre os Militares no Governo Fernando Henrique Cardoso. Revue Lusotopie. p. 399-418, 2003.

; MELO FILHO, Hugo Cavalcanti. Superior Tribunal Militar: entre o autoritarismo e a democracia. Dados, Rio de Janeiro, v. 47, n. 4, p. 763-797, 2004. UFPE, 2004.

Polícia Civil de Pernambuco: o desafio da reforma. Pernambuco: Ed.

. FHC, Forças Armadas e Polícia. Entre o autoritarismo e a democracia 1999-2002. Ed. Record, Rio de Janeiro, 2005.

. A militarização da ABIN. Folha de S. Paulo, 9 de janeiro, 2006.

Recebido: $17 / 07 / 2007$

Aceite final: 26/09/2007 